\title{
Highly efficient exclusion of alkali metal ions via electrostatic repulsion inside positively charged channels
}

Chenyang Zhang, Jun Tian, Shuaiwei Qi, Bing Yang, Zeyuan Dong*

State Key Laboratory of Supramolecular Structure and Materials, College of Chemistry, Jilin University, Qianjin Street 2699, Changchun 130012, China

E-mail: zdong@jlu.edu.cn

\section{Contents}

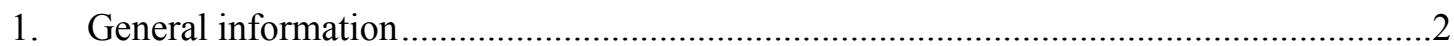

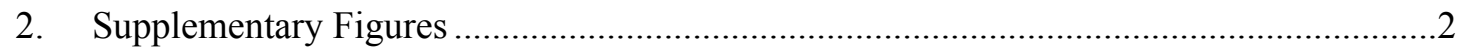

3. Planer Bilayer Lipid Membrane Conductance Experiment ...................................................5

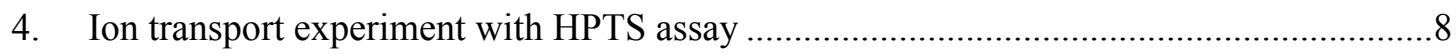

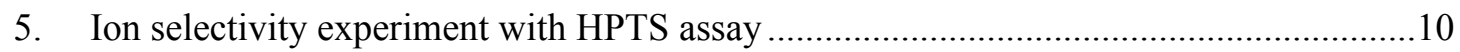

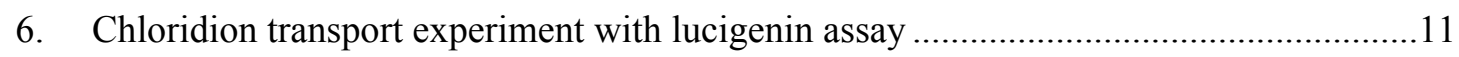

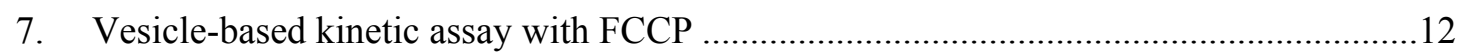

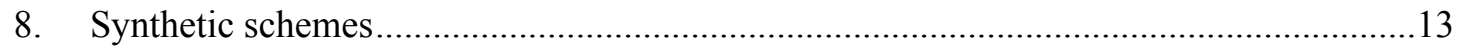

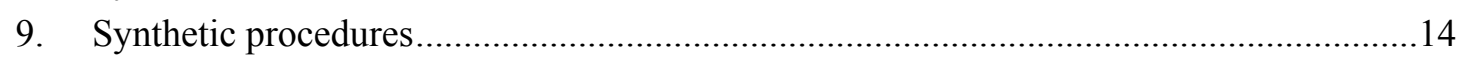

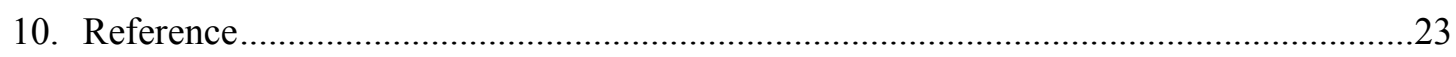




\section{General information}

All reactions were monitored via thin layer chromatography (TLC) method under ultraviolet light at $254 \mathrm{~nm}$ and/or $365 \mathrm{~nm}$. The products were purified through column chromatography via silica gel. All raw materials were purchased from Energy chemical company without further purification. Egg yolk phosphatidylcholine (EYPC), hydroxy-1,3,6-pyrenetrisulfonate (HPTS), lucigenin, carbonyl cyanide-4-(trifluoromethoxy)-phenylhydrazone (FCCP) and DiPhPC were purchased from Sigma-Aldrich company, and solvents used for synthesis were purchased from J\&K Scientific. Fluorescence experiments were recorded on Shimazu fluorescence spectrometer. ${ }^{1} \mathrm{H}$ NMR, ${ }^{13} \mathrm{C}$ NMR were recorded on Bruker AVANCEIII 500, Mass spectra were recorded on the Bruker MicrOTOF Q II, AFM images were recorded on multimode atomic force microscope with Nanoscope III, Veeco Metrology, Santa Barbara, CA) under tapping mode.

\section{Supplementary Figures}
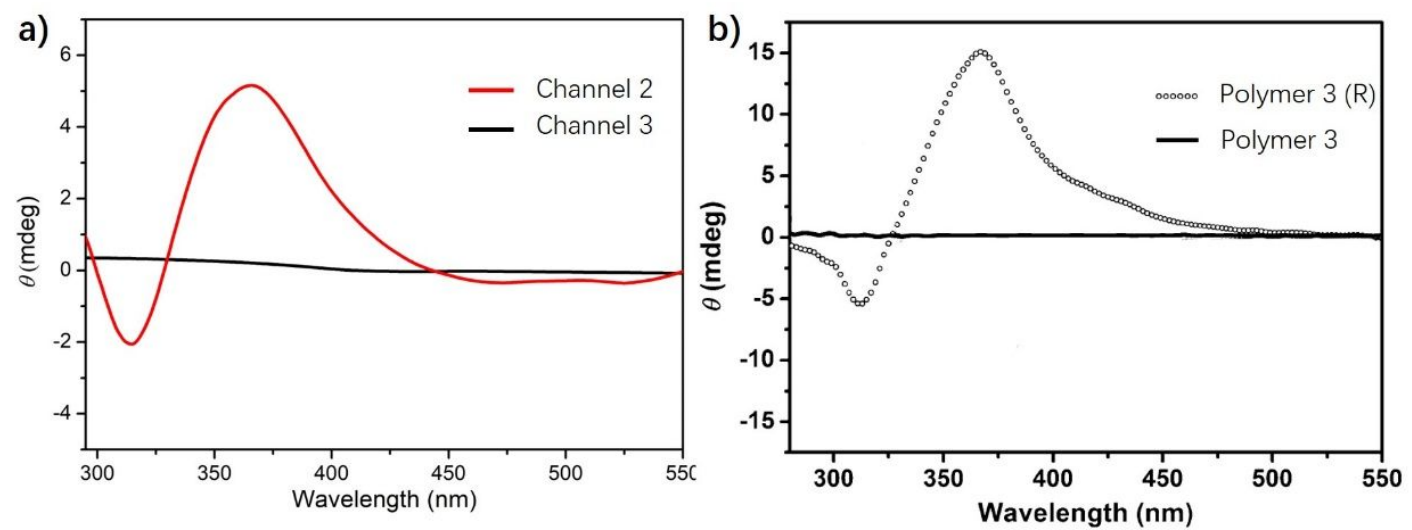

Figure S1. a) CD spectra for polymer 2 (red line) and polymer 3 (black line) in $\mathrm{CHCl}_{3}$ at $1 \mathrm{mg} / \mathrm{mL}$. b) CD spectra for polymer $\mathbf{3}$ and polymer $\mathbf{3}$ appending $(R)$-1-phenylethanamine. 


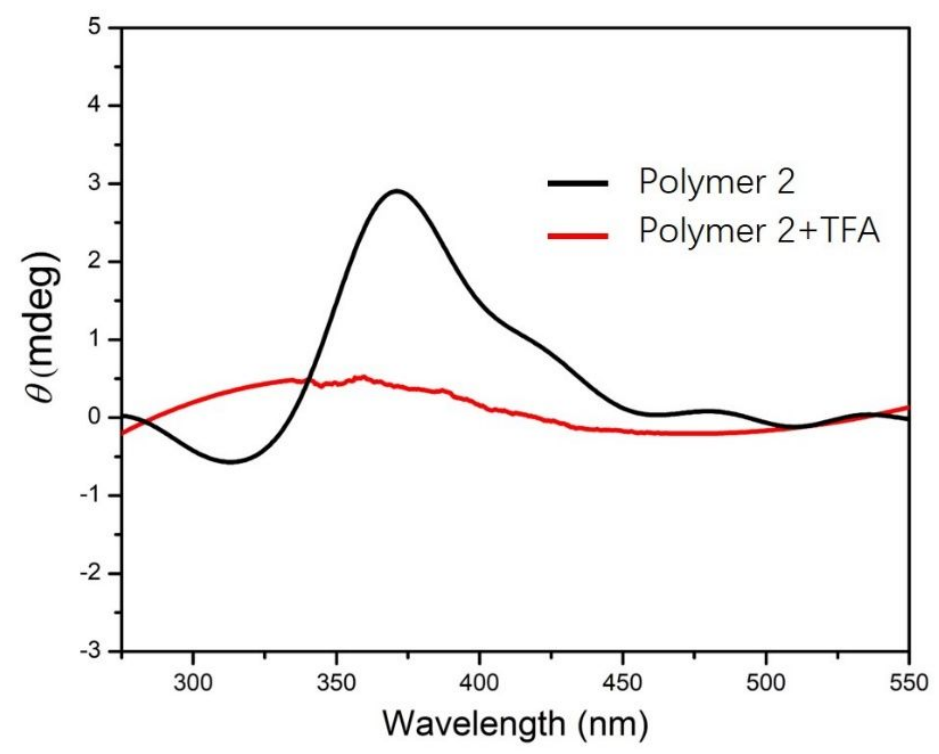

Figure S2. CD spectra for polymer 2 (black line) and polymer 2 mixed with excess amount (10 $\mu \mathrm{L})$ of TFA (red line) in $\mathrm{CHCl}_{3}$ at $0.5 \mathrm{~g} / \mathrm{L}$.

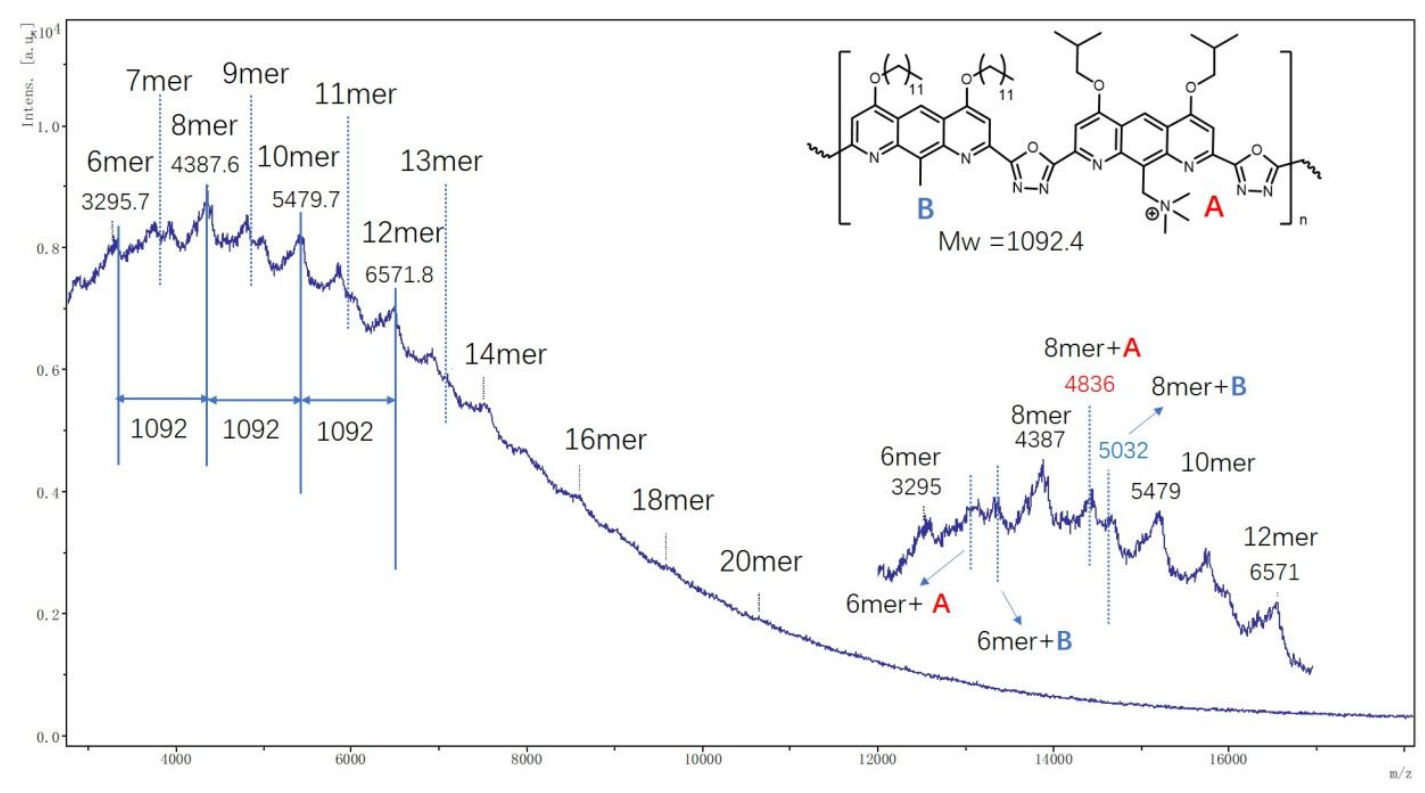

Figure S3. Maldi-TOF MS of helical polymer 1. Insets: polymeric sequence can be confirmed by the observation of molecular weight intervals of repeating units. 


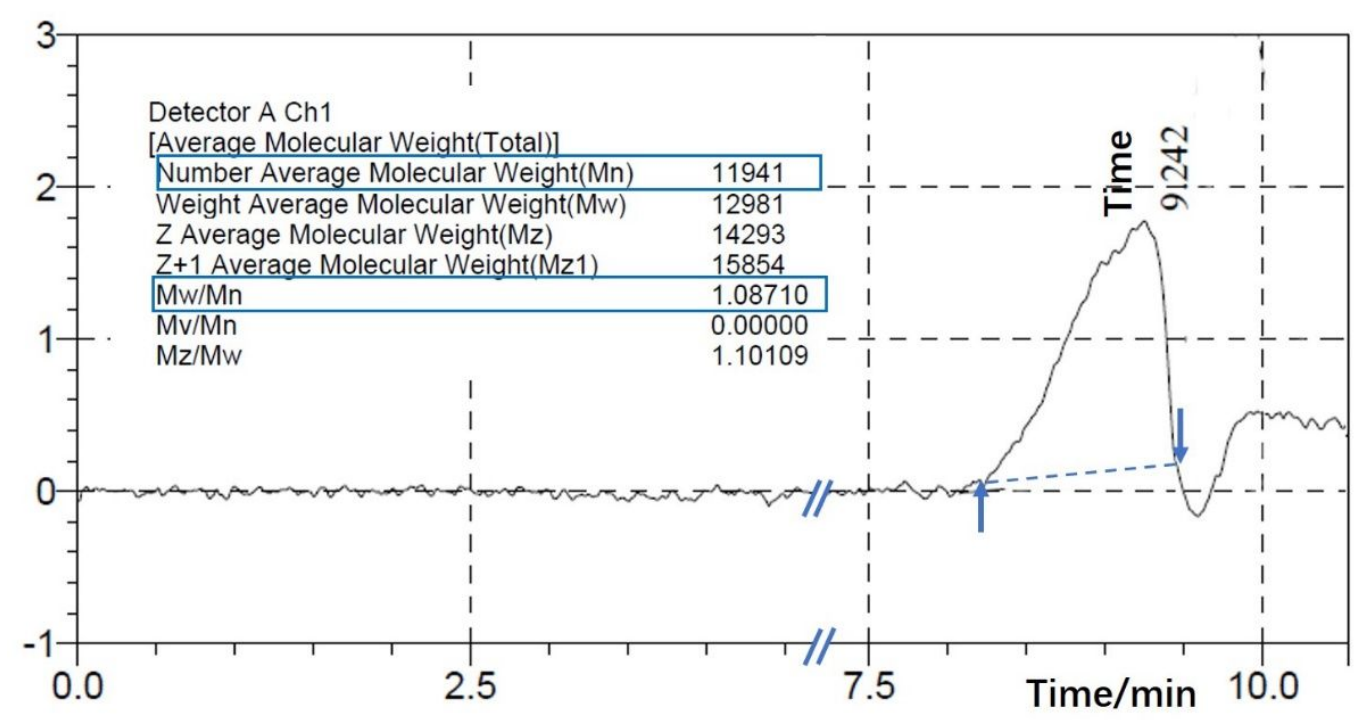

Figure S4. GPC trace of helical polymer 1 in DMF $(4 \mathrm{~g} / \mathrm{L})$ at $40^{\circ} \mathrm{C}$. The number average molecular weight and PDI of polymer $\mathbf{1}$ are listed in the figure.

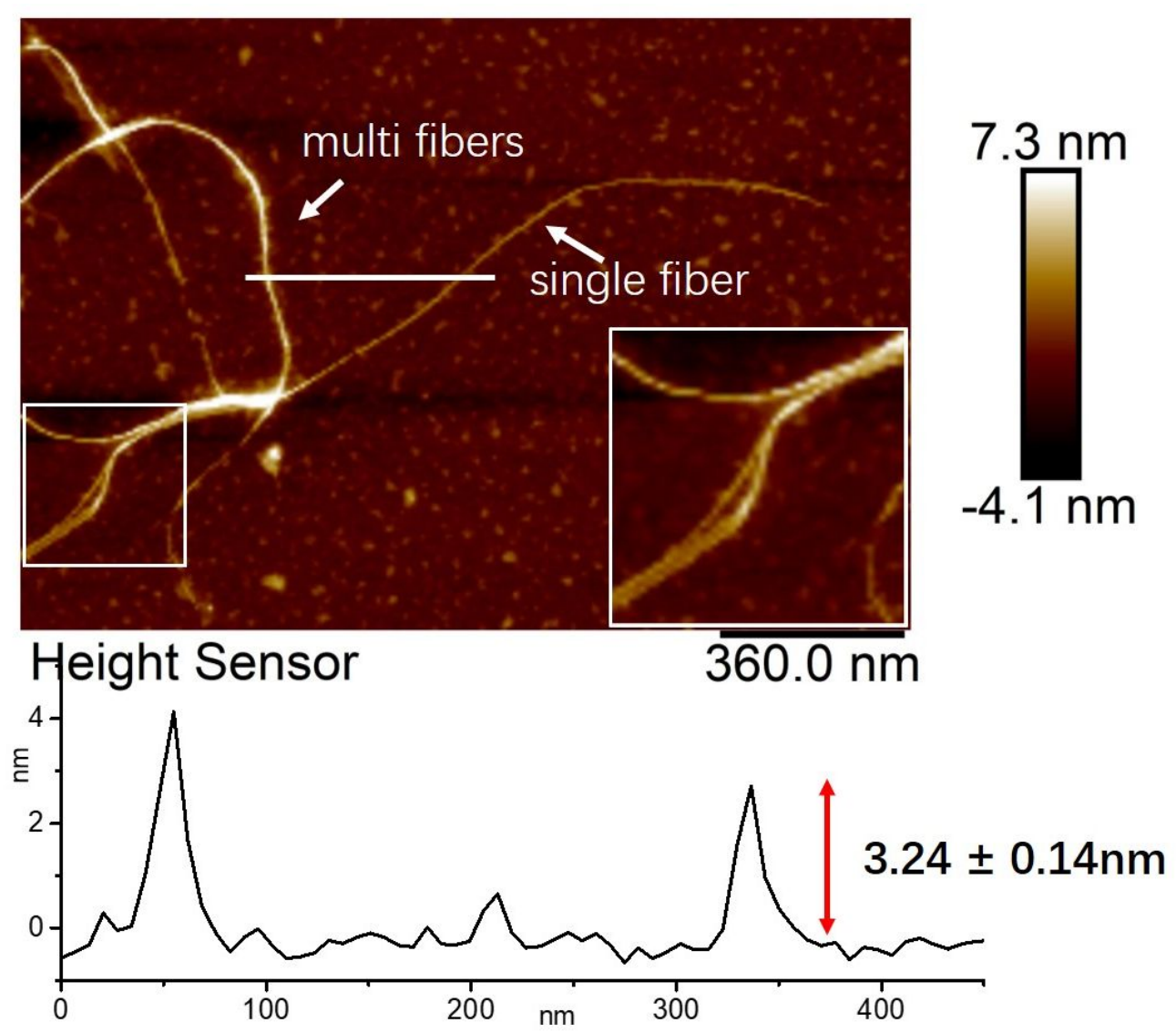

Figure S5. AFM image of helical polymer 1 on silicon surface. The height of profile is shown at the bottom, which is almost consistent with the peripheral diameter of channel 1. Insets: multiple nanowires can further self-assemble into thick fibers. 


\section{Planer Bilayer Lipid Membrane Conductance Experiment}

Symmetrical Planer Lipid Bilayer Conductance Experiment

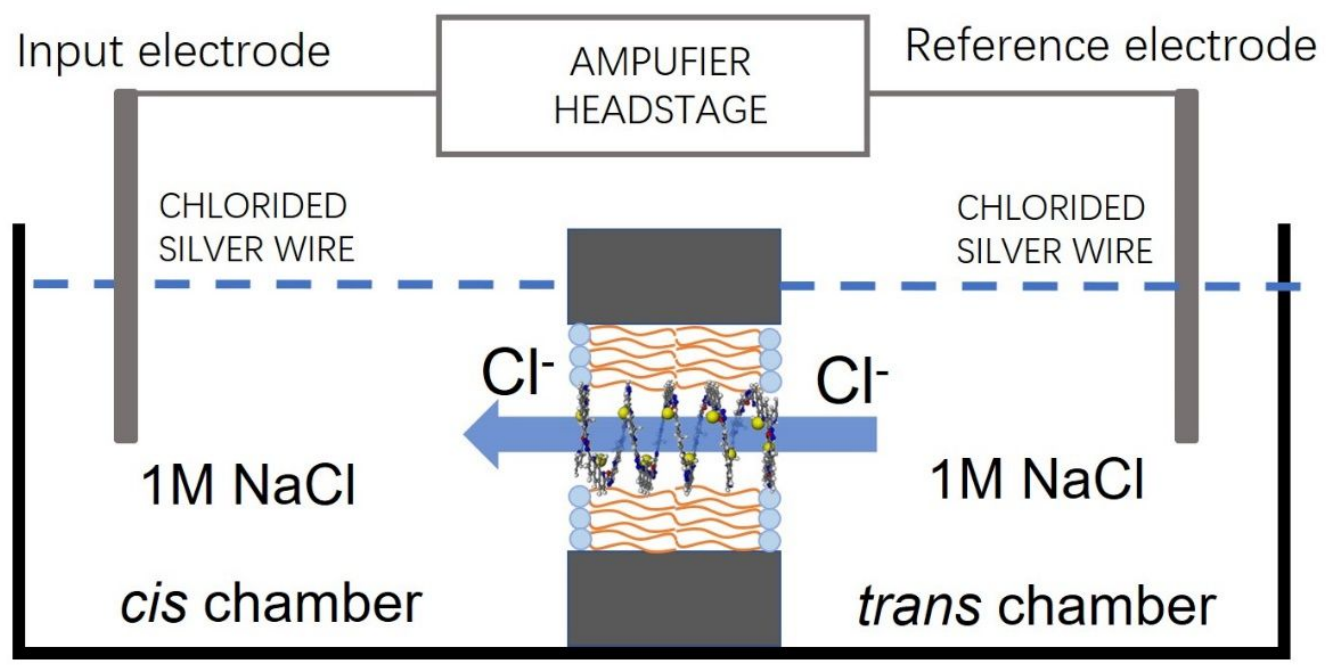

Figure S6. A typical setup of planer bilayer lipid membranes conductance experiment.

DiPhPC $(10 \mathrm{mg})$ solution in $\mathrm{CHCl}_{3}$ was divided into 20 vials, then the solvent was dried under $\mathrm{N}_{2}$ flow and the residual solvent was removed on vacuum for 2 hours. The lipid in vial was stored under $-20^{\circ} \mathrm{C}$ for next use. Before BLM experiment, return the vial to room temperature and the lipid was suspended in $20 \mu \mathrm{L} n$-decane. $0.3 \mu \mathrm{L}$ lipid suspension was precoated around a micropore of $200 \mu \mathrm{m}$ in the middle of the trans chamber. Both cis and trans chambers were filled with $1 \mathrm{M} \mathrm{NaCl}$ solution and connected via $200 \mu \mathrm{m}$ micropore. The input electrode $(\mathrm{Ag} / \mathrm{AgCl})$ was inserted into cis chamber and the reference electrode $(\mathrm{Ag} / \mathrm{AgCl})$ was set into trans chamber. $0.5 \mu \mathrm{L}$ lipid suspension in $n$-decane was dropped on a slim glass rod and formed a membrane on the micropore to separate from cis and trans chambers. $1 \mu \mathrm{L}$ channel solution in DMSO was added into cis chamber under stirring over $5 \mathrm{~min}$, and the voltage on the electrodes was regulated from $-200 \mathrm{mV}$ to $200 \mathrm{mV}$, in order to obtain the current-voltage plot. Current signal was collected by Warner BC-535 amplifier (Warner Instruments), digitized by PowerLab (ADinstruments) and stored by using the LabChart 7 (ADinstruments).

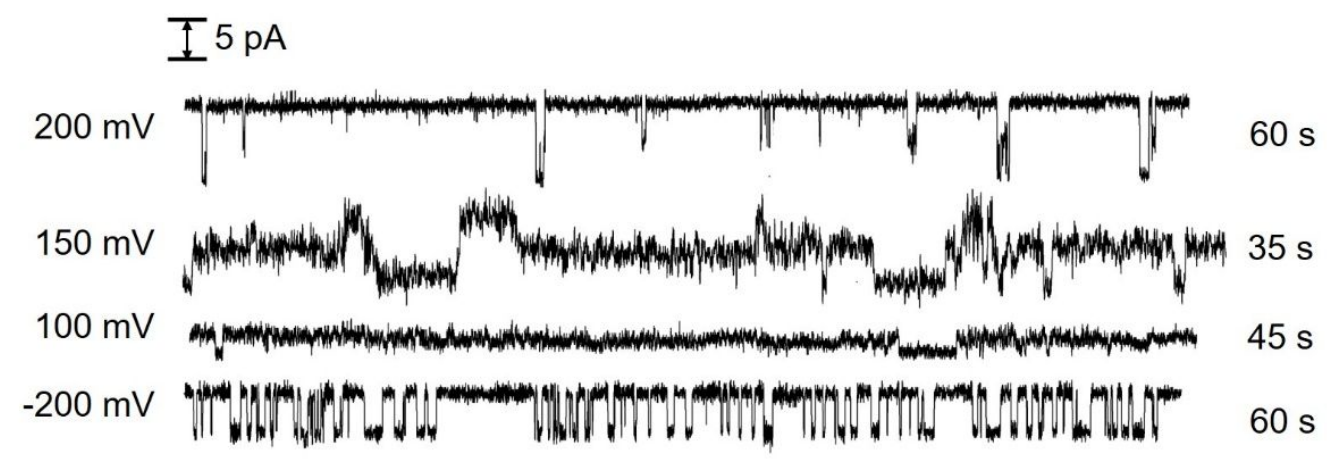

Figure S7. Current signals of channel $\mathbf{1}$ in symmetrical solution from $150 \mathrm{mV}$ to $-200 \mathrm{mV}$. 


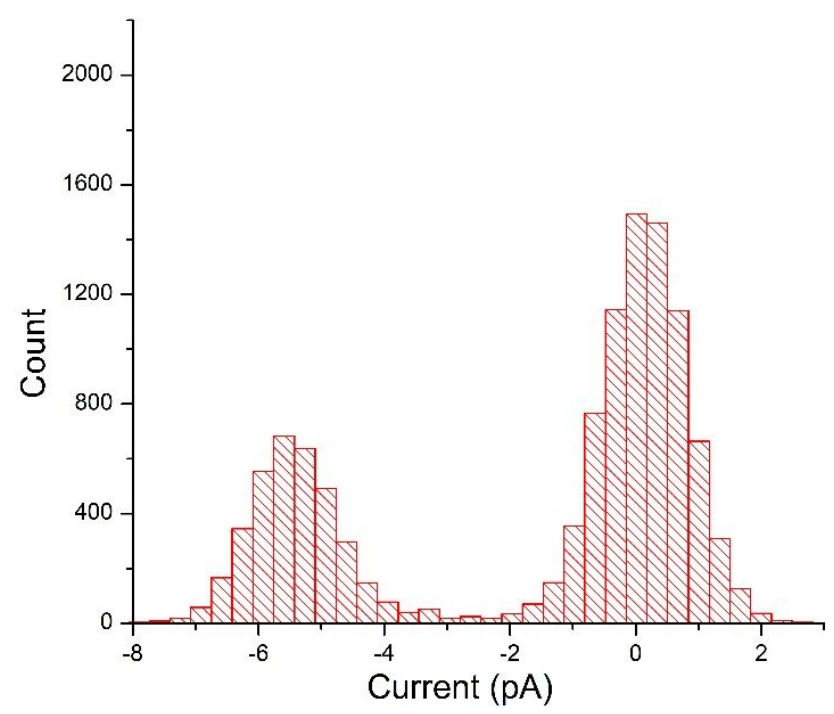

Figure S8. Histogram plot of the currents of channel $\mathbf{1}$ at $-200 \mathrm{mV}$.

\section{Asymmetrical Planer Bilayer Lipid Conductance Experiments for Anion/Cation Selectivity}

The preparation of bilayer lipid is similar to that in the symmetrical planer lipid bilayer conductance experiment. The lipid suspension was precoated around a $200 \mu \mathrm{m}$ micropore in the middle of trans chamber. Cis chamber was filled with $0.5 \mathrm{M} \mathrm{NaCl}$ solution and trans chamber was filled with $1 \mathrm{M} \mathrm{NaCl}$ solution. Two $\mathrm{Ag} / \mathrm{AgCl}$ electrodes were set in each chamber. The input electrode was inserted into cis chamber and the reference electrode was set in trans chamber. $0.5 \mu \mathrm{L}$ lipid suspension in $n$-decane was dropped on a slim glass rod and formed a membrane on the $200 \mu \mathrm{m}$ micropore to separate from cis and trans chamber. $1 \mu \mathrm{L}$ channel solution in DMSO was added into cis chamber under stirring over $5 \mathrm{~min}$ and the voltage on the electrodes was regulated from $-200 \mathrm{mV}$ to $200 \mathrm{mV}$, in order to obtain the current-voltage plot. The whole experiment was measured on the Axon patch clamp station. Current signal was collected by Warner BC-535 amplifier (Warner Instruments), digitized by PowerLab (ADinstruments) and stored by using the LabChart 7 (ADinstruments).

The $\mathrm{Cl}^{-} / \mathrm{Na}^{+}$ratio was calculated via the Goldman-Hodgkin-Katz (GHK) voltage Equation:

$$
\mathrm{P}_{\mathrm{A}-} / \mathrm{P}_{\mathrm{M}^{+}}=\left[\mathrm{a}_{\mathrm{M}} \text { cis }-\mathrm{a}_{\mathrm{M}} \text { trans } \exp \left(-\mathrm{V}_{\mathrm{r}} \mathrm{F} / \mathrm{RT}\right)\right] /\left[\mathrm{a}_{\mathrm{A}} \text { cis } \exp \left(-\mathrm{V}_{\mathrm{r}} \mathrm{F} / \mathrm{RT}\right)-\mathrm{a}_{\mathrm{A}} \text { trans }\right]
$$

(Equation S1)

$\mathrm{P}_{\mathrm{A}-} / \mathrm{P}_{\mathrm{M}+}$ : anion/cation permeability ratio, $\mathrm{a}_{\mathrm{M}}$ cis: anion activity in cis chamber, $\mathrm{V}_{\mathrm{r}}$ : reversal potential, F: Faraday constant, R: gas constant, $\mathrm{T}$ : room temperature. $\mathrm{RT} / \mathrm{F}=25.69 \mathrm{mV}$ at $25^{\circ} \mathrm{C}$. 


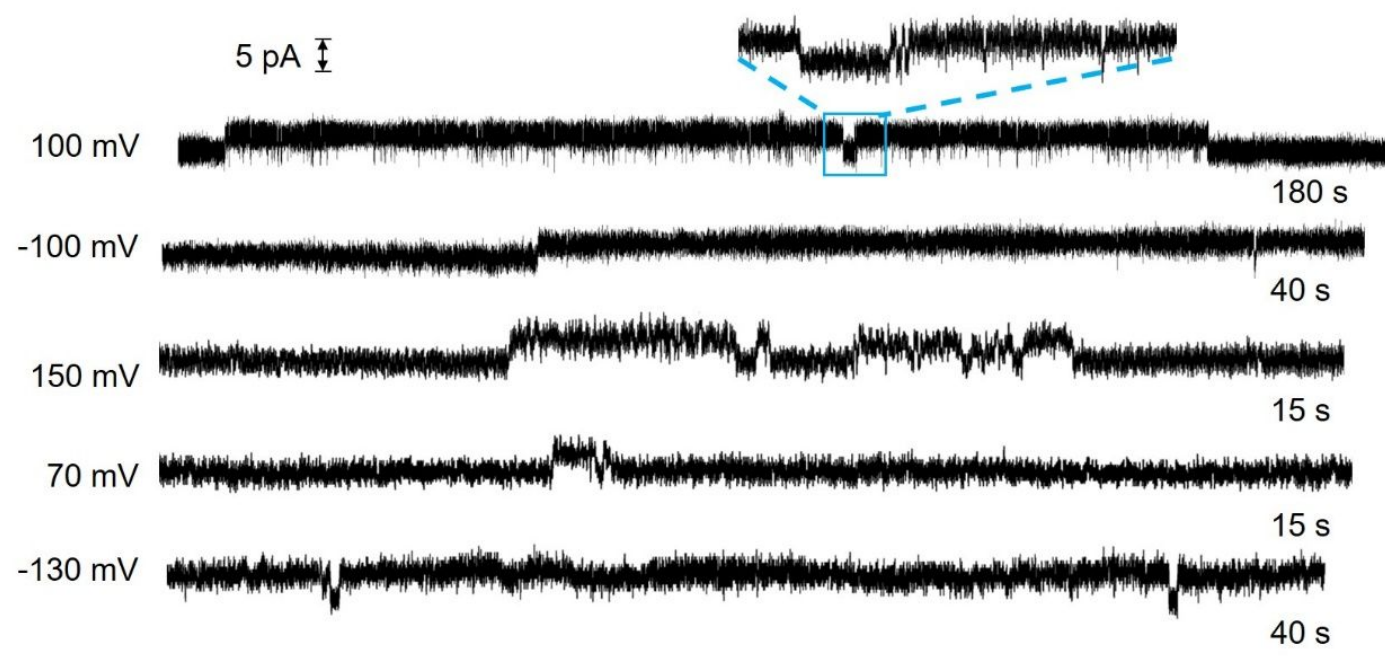

Figure S9. Single-channel currents of channel 1 in asymmetrical solution.

\section{Asymmetrical Planer Bilayer Lipid Conductance Experiment for $\mathrm{Cl}^{-} / \mathrm{SO}_{4}{ }^{2-}$ Selectivity}

The preparation of bilayer lipid was same as the symmetrical planer lipid bilayer conductance experiment. Cis chamber was filled with $0.5 \mathrm{M} \mathrm{Na}_{2} \mathrm{SO}_{4}$ solution and trans chamber was filled with $1 \mathrm{M} \mathrm{NaCl}$ solution. $\mathrm{Ag} / \mathrm{AgCl}$ electrodes were set in each chamber to record membrane currents. The input electrode was inserted into cis chamber and the reference electrode into trans chamber. $0.5 \mu \mathrm{L}$ lipid suspension in n-decane was dropped on a slim glass rod and formed a membrane on the micropore to separate two chambers. $1 \mu \mathrm{L}$ channel solution in DMSO was added into cis chamber under stirring over 5 minutes and the voltage on the electrodes was changed from $-200 \mathrm{mV}$ to $200 \mathrm{mV}$. The whole experiment was measured on the Axon patch clamp station. Current signal was collected by Warner BC-535 amplifier (Warner Instruments), digitized by PowerLab (ADinstruments) and stored by using the LabChart 7 (ADinstruments).

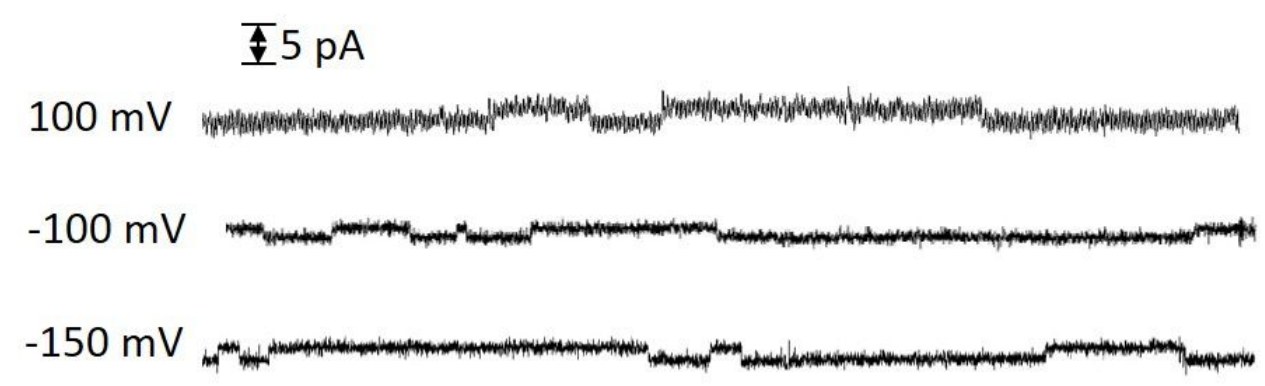

Figure S10. Current signals of channel 1 in asymmetrical solution from $100 \mathrm{mV}$ to $-150 \mathrm{mV}$. 


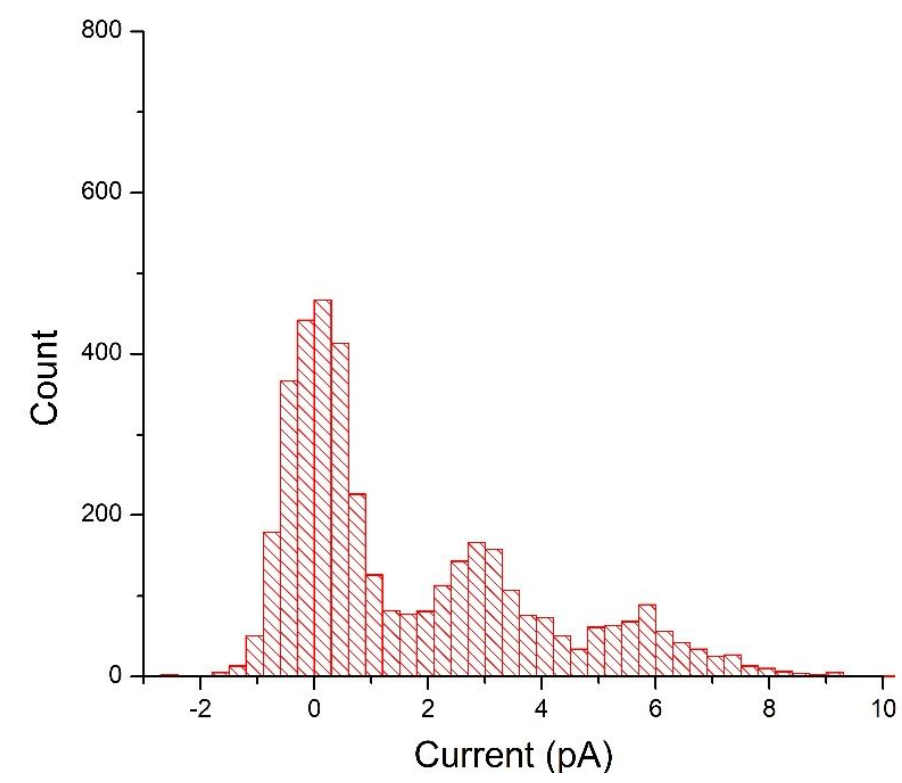

Figure S11. Histogram plot of the currents of channel 1 at $150 \mathrm{mV}$ under $\mathrm{Cl}^{-} / \mathrm{SO}_{4}{ }^{2-}$ selectivity experiments.

\section{Ion transport experiment with HPTS assay}

Preparation of LUVs: $2 \mathrm{~mL}$ EYPC solution in $\mathrm{CHCl}_{3}$ (18 $\mathrm{mg}$ EYPC and 10\% cholesterol) was divided into 2 vials, then the solvent was blown dry via $\mathrm{N}_{2}$ and the residual solvent was removed on vacuum for 3 hours. The lipid in vials was stored under $-20{ }^{\circ} \mathrm{C}$ for future use. Before preparing vesicles, the vials were kept at room temperature and $1 \mathrm{~mL}$ HEPES buffer solution $(100 \mathrm{mM} \mathrm{NaCl}, 10 \mathrm{mM}$ HEPES, $\mathrm{pH}=7.0)$ mixed with $1 \mathrm{mM}$ HPTS was added. This mixture was placed in a $37^{\circ} \mathrm{C}$ incubator for 2 hours and suffered 10 freeze-melt cycles via liquid nitrogen and water bath. Then, the suspension was filtered via $0.22 \mu \mathrm{m}$ polycarbonate membrane to form uniform vesicles. Excess lipids and fluorescence dye were removed by G50 with the identical buffer solution. The LUVs suspension was stored under $4{ }^{\circ} \mathrm{C}$ and used in 48 hours.

Fluorescent experiments: Fluorescent experiments were measured via Shimadzu RF-5301PC fluorescence spectrophotometer in time scanning mode. In a $1.5 \mathrm{~mL}$ cuvette, $50 \mu \mathrm{L}$ LUVs suspensions were mixed with $950 \mu$ L HEPES buffer solution $(100 \mathrm{mM} \mathrm{NaCl}, 10 \mathrm{mM}$ HEPES, $\mathrm{pH}=6.0$ ). Fluorescence intensity $\left(\mathrm{E}_{\mathrm{t}}\right)$ was continuously monitored at $510 \mathrm{~nm}$ (Excitation wavelength: $460 \mathrm{~nm}$ ). After $50 \mathrm{~s}, 10 \mu \mathrm{L}$ polymer solution in DMSO was added into the suspension under stirring and $10 \mu \mathrm{L} 40 \%$ Triton X-100 solution was added at 350 s to stop this test. The data was continuously measured until the fluorescence intensity $\left(\mathrm{E}_{\infty}\right)$ did not change. The collected data were normalized according to the equation:

$$
\mathrm{R}=\left(\mathrm{E}_{\mathrm{t}}-\mathrm{E}_{\infty}\right) /\left(\mathrm{E}_{0}-\mathrm{E}_{\infty}\right)
$$

$\mathrm{R}$ : normalized fluorescence intensity.

$\mathrm{E}_{0}$ : the initial emission intensity. 


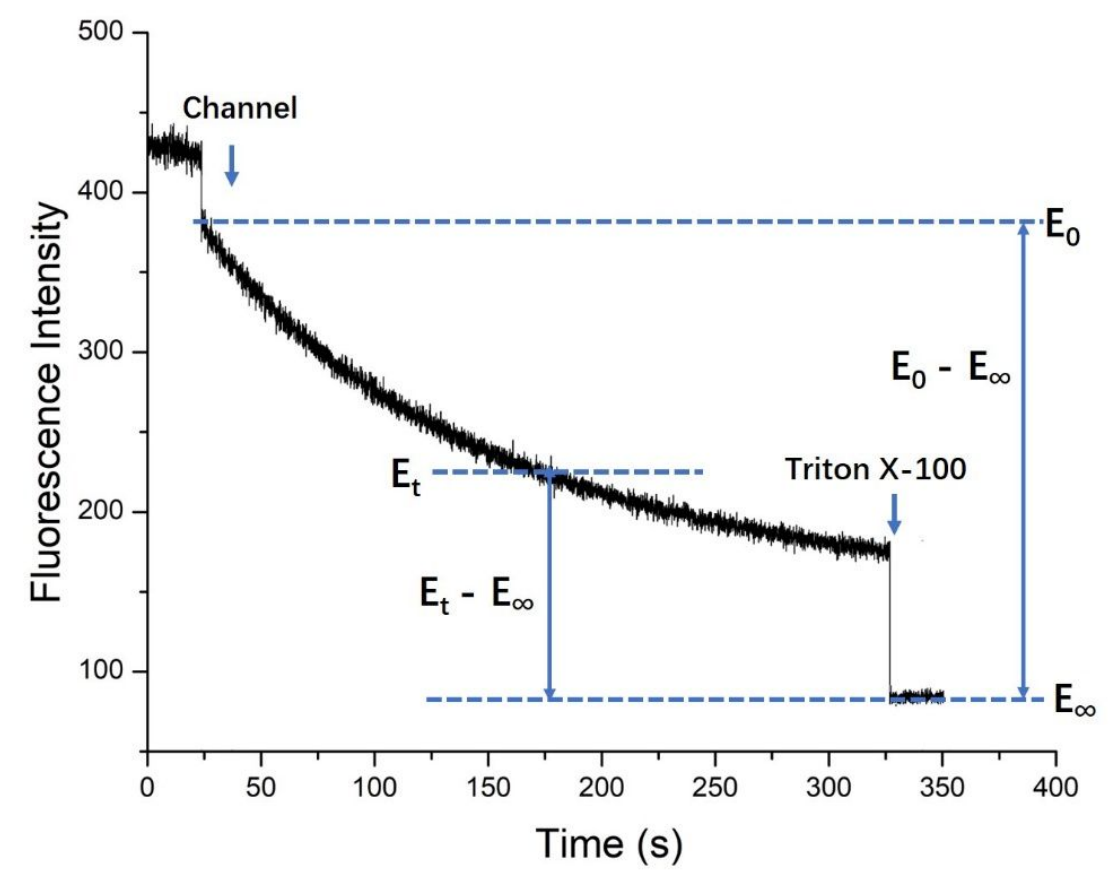

Figure S12. Diagrammatic drawing for vesicle-based kinetic assay.

$\mathrm{Y}$ was defined as transmembrane transport activity $(\mathrm{Y}=1-\mathrm{R}$, in this fluorescence quenching experiment). The effective concentration $\mathrm{EC}_{50}$ (concentration needed to reach $50 \%$ transport activity at 300s) and Hill coefficient $n$ can be calculated via the Hill equation:

$$
\mathrm{Y}=Y_{\infty}+\left(Y_{0}-Y_{\infty}\right) /\left(1+\left(c / E C_{50}\right)^{n}\right)
$$

(Equation S2)

$Y_{0}$ is the transport activity without channels, $Y_{\infty}$ is the transport activity mixed with excess channels (in most cases, this value defaults to 1). Value $c$ is the channels concentration.

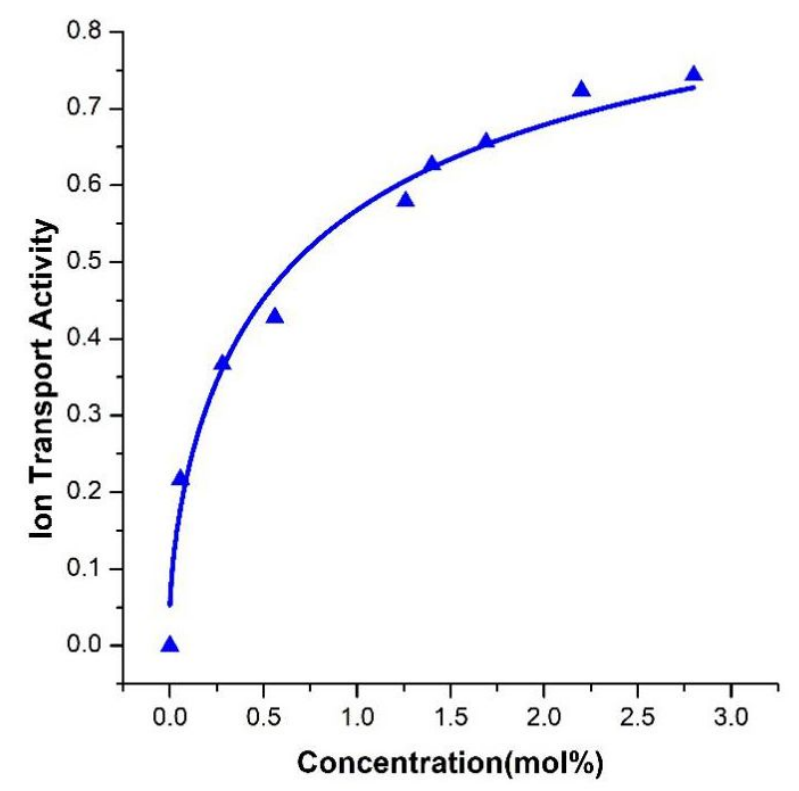

Figure S13. Fitted curve of the normalized transport activities for channel 1 via the Hill equation. 


\section{Ion selectivity experiment with HPTS assay}

Preparation of LUVs: this part is same as ion transport experiment with HPTS assay. Anion selectivity experiment:

Fluorescent experiments were measured via Shimadzu RF-5301PC fluorescence spectrophotometer in time scanning mode. In a $1.5 \mathrm{~mL}$ cuvette, $50 \mu \mathrm{L}$ LUVs suspensions were mixed with $950 \mu \mathrm{L}$ HEPES buffer solution (100 mM NaX, X=F, Cl, Br and I, $10 \mathrm{mM}$ HEPES, $\mathrm{pH}=6.0$ ). Fluorescence intensity $\left(\mathrm{E}_{\mathrm{t}}\right)$ was continuously monitored at $510 \mathrm{~nm}$ (Excitation wavelength: $460 \mathrm{~nm}$ ). After $50 \mathrm{~s}, 10 \mu \mathrm{L}$ polymer solution in DMSO was added into the suspension under stirring and $10 \mu \mathrm{L} 40 \%$ Triton X-100 solution was added at 350 s to stop this test. The data was continuously measured until the fluorescence intensity $\left(\mathrm{E}_{\infty}\right)$ did not change. The collected data were normalized according to the equation:

$$
\mathrm{R}=\left(\mathrm{E}_{\mathrm{t}}-\mathrm{E}_{\infty}\right) /\left(\mathrm{E}_{0}-\mathrm{E}_{\infty}\right)
$$

$\mathrm{R}$ : normalized fluorescence intensity.

$\mathrm{E}_{0}$ : the initial emission intensity.

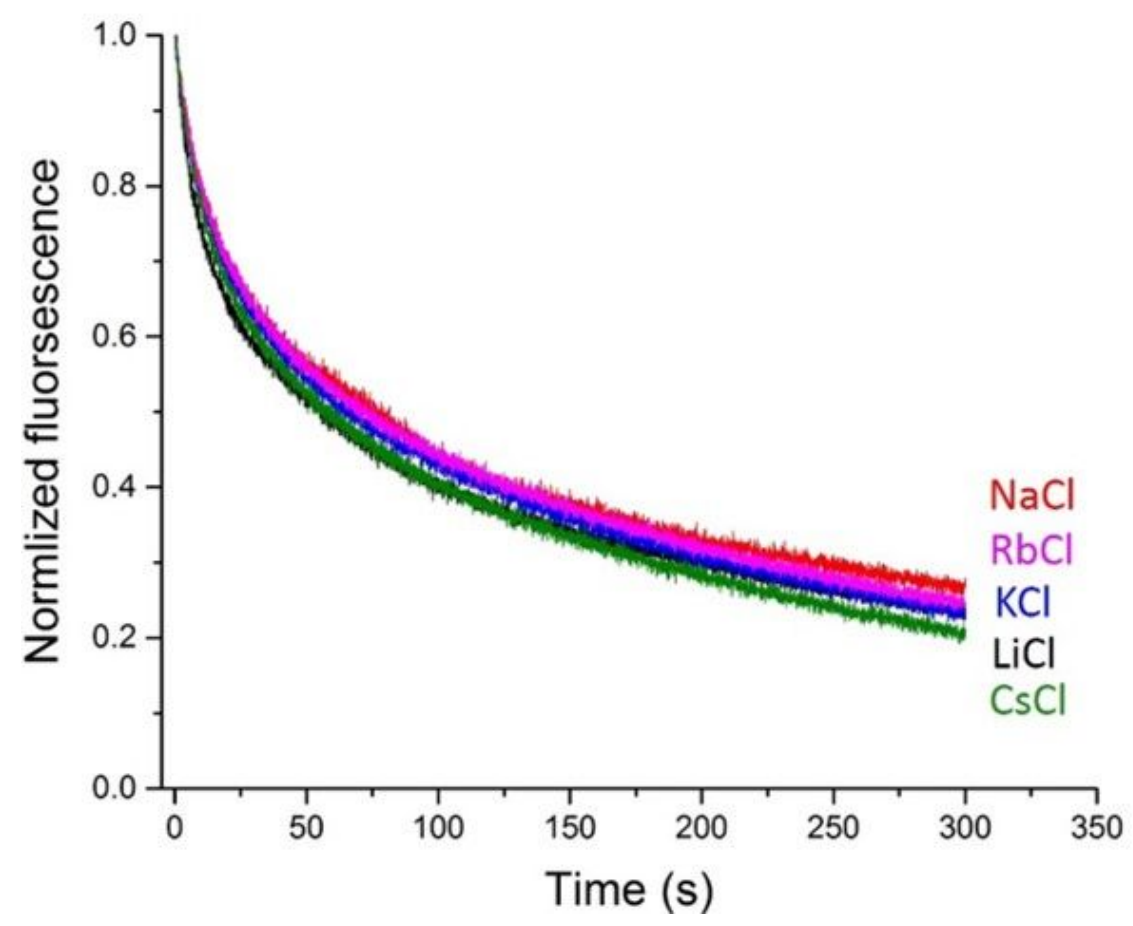

Figure S14. Normalized cation selectivity transport activities of channel 1 through HPTS assay. 


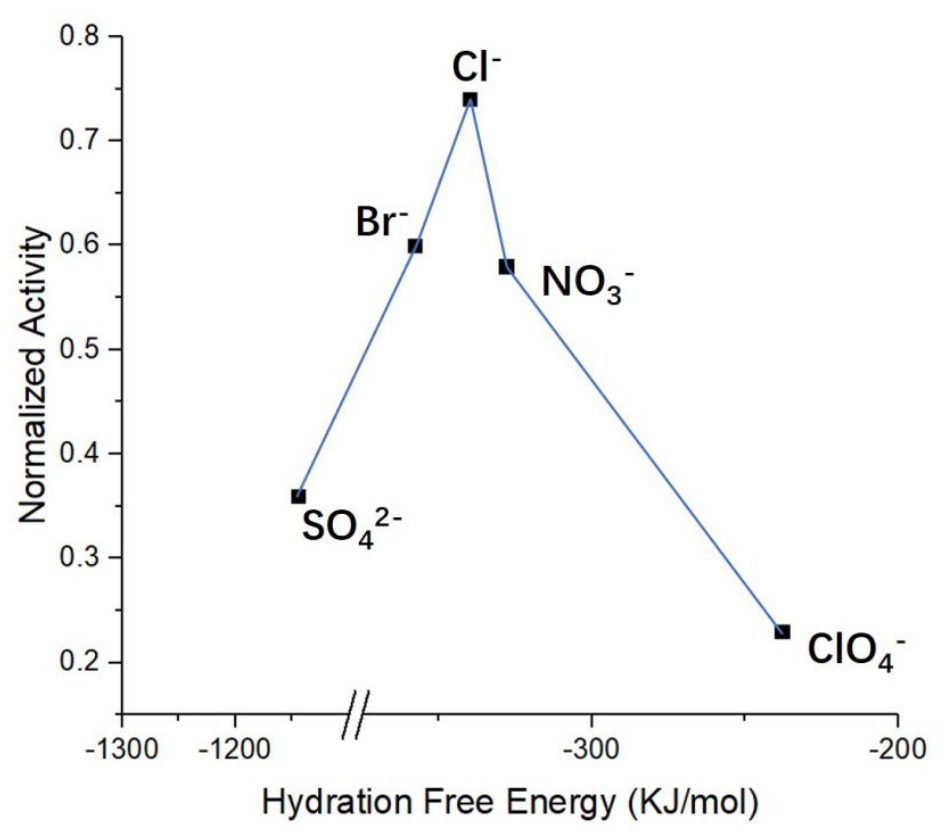

Figure S15. Diagram of free energy of ionic hydration and normalized ion transport activities of channel 1.

\section{Cation selectivity experiment:}

The process was similar to that in anion selectivity experiment, except that the external solution was changed into $\mathrm{MCl}$ buffer $\left(\mathrm{MCl}, \mathrm{M}=\mathrm{Li}^{+}, \mathrm{Na}^{+}, \mathrm{K}^{+}, \mathrm{Rb}^{+}\right.$, and $\left.\mathrm{Cs}^{+}\right)$

\section{Chloridion transport experiment with lucigenin assay}

Preparation of LUVs: EYPC solution in $\mathrm{CHCl}_{3}(18 \mathrm{mg}$ EYPC and $10 \%$ cholesterol) was divided into 2 vials, then the solvent was blown dry under $\mathrm{N}_{2}$ and the residual solvent was removed in a vacuum for 3 hours. The lipid in vial was stored under $-20^{\circ} \mathrm{C}$ for future use. Before preparing vesicles, return the vial to room temperature and $1 \mathrm{~mL} 200 \mathrm{mM} \mathrm{NaNO}_{3}$ solution mixed with $1 \mathrm{mM}$ lucigenin was added. This mixture was placed in a $37^{\circ} \mathrm{C}$ incubator for 2 hours and suffered 10 freeze-melt cycles via liquid nitrogen and water bath. Then, the suspension was filtered via $0.22 \mu \mathrm{m}$ polycarbonate membrane to form uniform vesicles. Excess lipids and fluorescence dye were removed by G50 against the $200 \mathrm{mM} \mathrm{NaNO}{ }_{3}$ solution. The LUVs suspension was stored under $4{ }^{\circ} \mathrm{C}$ and used in 48 hours.

Fluorescent experiments: Fluorescent experiments were measured via Shimadzu RF-5301PC fluorescence spectrophotometer in time scanning mode. In a $1.5 \mathrm{~mL}$ cuvette, $50 \mu \mathrm{L}$ LUVs suspensions were mixed with $950 \mu \mathrm{L} 200 \mathrm{mM} \mathrm{NaNO}_{3}$ and $20 \mathrm{mM} \mathrm{NaCl}$ solution (in this experiment, $\mathrm{NaNO}_{3}$ was used to equilibrate the $\mathrm{Cl}^{-}$influx). Fluorescence intensity $\left(\mathrm{E}_{\mathrm{t}}\right)$ was continuously monitored at $505 \mathrm{~nm}$ (Excitation wavelength: $455 \mathrm{~nm}$ ). After $50 \mathrm{~s}, 10 \mu \mathrm{L}$ channel solution in MeCN was added into the suspension under stirring and $10 \mu \mathrm{L} 40 \%$ Triton X-100 solution was added at $300 \mathrm{~s}$ to stop this test. The data was continuously measured until the fluorescence intensity $\left(\mathrm{E}_{\infty}\right)$ did not change. The collected data were normalized according to the equation: 


$$
\mathrm{R}=\left(\mathrm{E}_{\mathrm{t}}-\mathrm{E}_{\infty}\right) /\left(\mathrm{E}_{0}-\mathrm{E}_{\infty}\right)
$$

$\mathrm{R}$ : normalized fluorescence intensity.

$\mathrm{E}_{0}$ : the initial emission intensity.
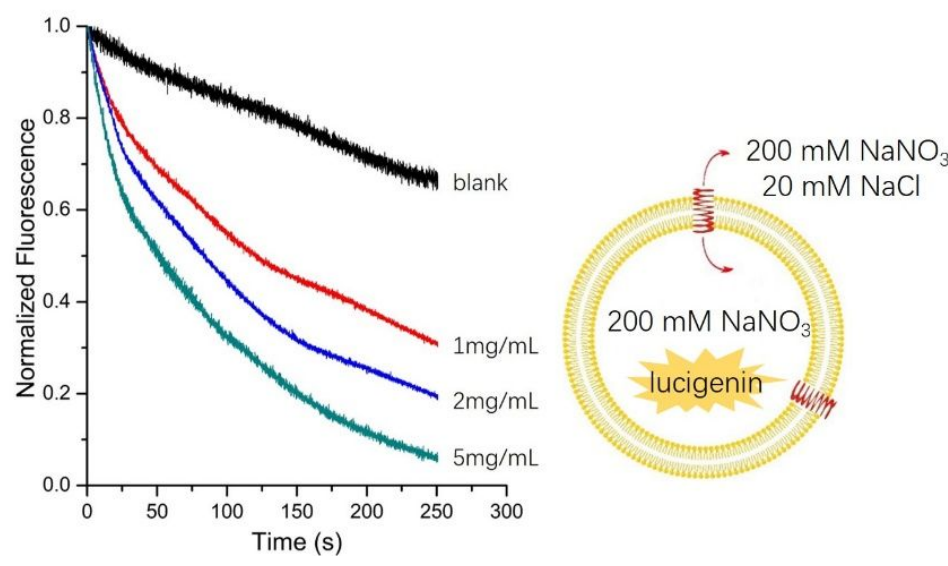

Figure S16. Normalized chloride ion transport activity with different concentrations of channel 1.

\section{Vesicle-based kinetic assay with FCCP}

Preparation of LUVs: this section is the same as the method in ion transport experiment.

Fluorescent experiments: All the experiments were carried out by Shimadzu RF-5301PC fluorescence spectrophotometer under time scanning mode in $1.5 \mathrm{~mL}$ quartz cuvette. $50 \mu \mathrm{L}$ LUVs suspensions were mixed with $950 \mu \mathrm{L}$ HEPES buffer solution $(100 \mathrm{mM} \mathrm{NaCl}$ solution, $10 \mathrm{mM}$ HEPES, $\mathrm{pH}=6.00)$ in the cuvette. The fluorescence intensity $\left(\mathrm{E}_{\mathrm{t}}\right)$ was continuously monitored at $510 \mathrm{~nm}$ (excited at $460 \mathrm{~nm}$ ). After $50 \mathrm{~s}, 10 \mu \mathrm{L}$ channel solution and FCCP solution (the same concentration as channels) in DMSO was added into the suspension under stirring. $10 \mu \mathrm{L} 50 \%$ Triton $\mathrm{X}-100$ solution was added at $350 \mathrm{~s}$ to stop this test. The data was continuously measured until the fluorescence intensity $\left(\mathrm{E}_{\infty}\right)$ had no any change. 


\section{Synthetic schemes}

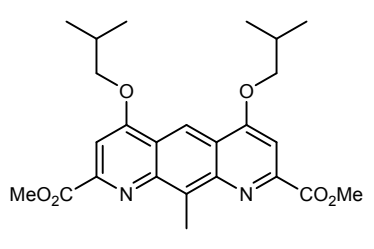

4<smiles>CC(C)COc1cc(C(=O)O)nc2c(C[N+](C)(C)C)c3nc(C(=O)O)cc(OCC(C)C)c3cc12</smiles>

7

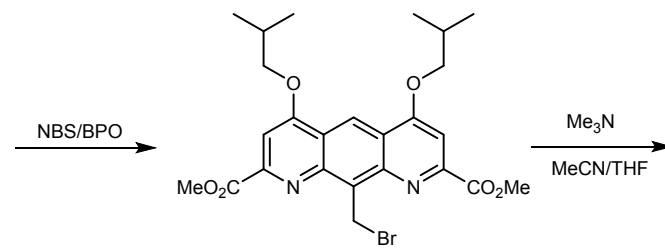

5
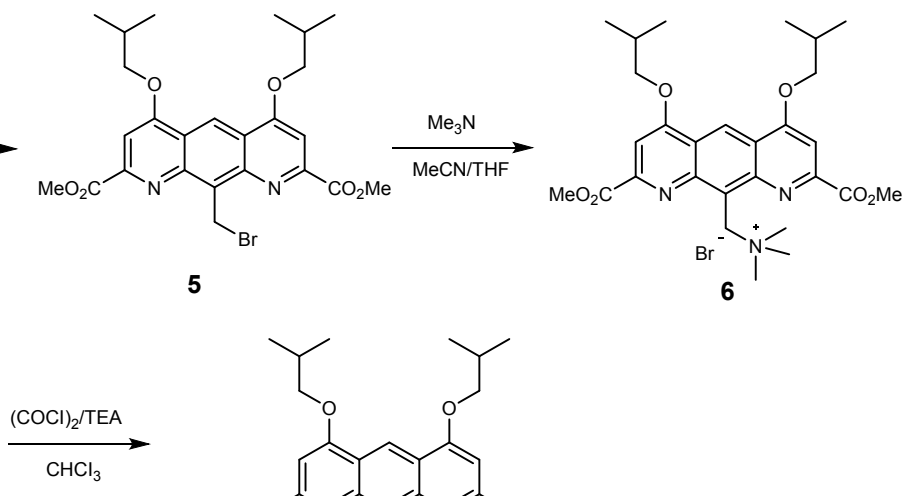<smiles>CC(C)COc1cc(C(=O)Cl)nc2c(C[N+](C)(C)C)c3nc(C(=O)Cl)cc(OCC(C)C)c3cc12</smiles>

8<smiles>CCOc1cc(C(C)=O)nc2c(C)c3nc(C(C)=[V])cc(OC)c3cc12</smiles>

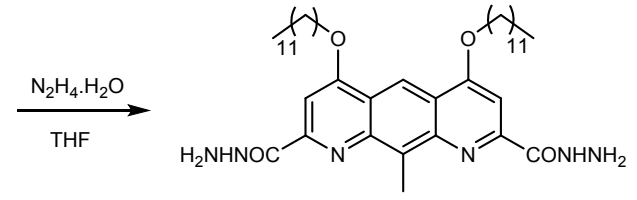

10

Scheme S1. Synthesis of monomer $\mathbf{8}$ and $\mathbf{1 0 .}$

$8+10 \underset{\mathrm{Et}_{3} \mathrm{~N} / \mathrm{CHCl}_{3}}{\stackrel{\text { РyBOP }}{\longrightarrow}}$

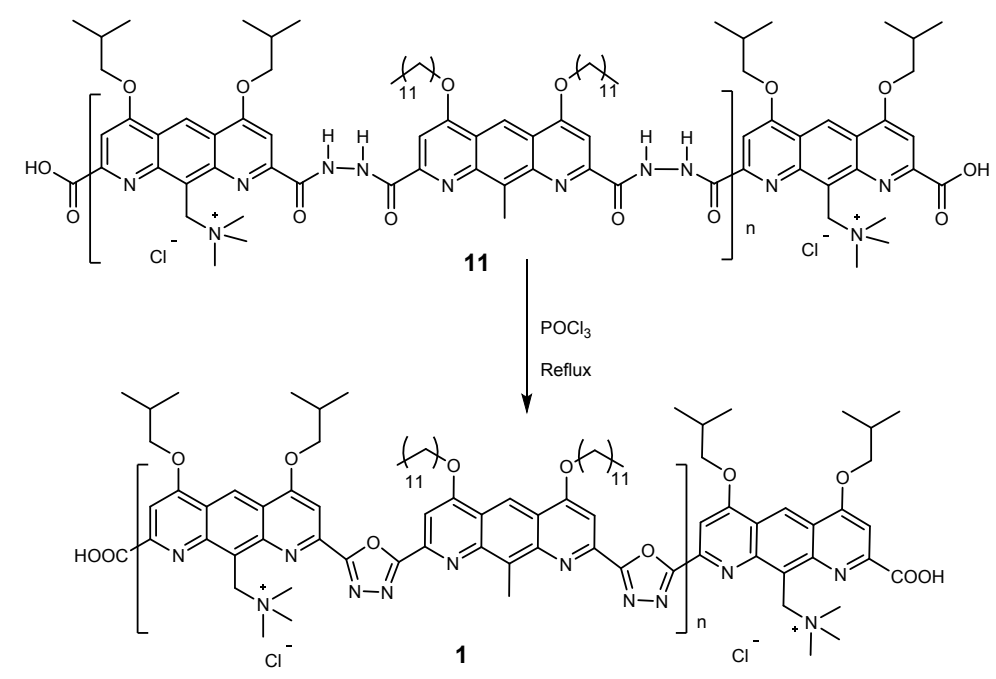

Scheme S2. Synthesis of compound 1

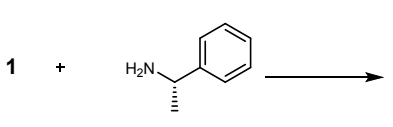<smiles></smiles><smiles>CCOc1cc(C(=N)O)nc2c(C)c3nc(-c4nnc(-c5cc(OCC(C)C)c6cc7c(OCC(C)C)cc(C(=O)N[C@H](C)c8ccccc8)nc7c(C[N+](C)(C)C)c6n5)o4)cc(O[Al])c3cc12</smiles>

Scheme S3. Synthesis of compound 2 


\section{Synthetic procedures}<smiles></smiles>

Compound 4. Compounds 4 was synthesized according to the previously reported methods and fully characterized. ${ }^{\mathrm{S} 1}$<smiles>[B]Cc1nc(OC(C)=O)cc(OCC(C)C)c1Cc1cc(OCC(C)C)cc2cc(OC)nc(O)c12</smiles>

Compound 5. In a $300 \mathrm{~mL}$ round-bottomed flask, compound 4 (5.00 g, $2.2 \mathrm{mmol})$, NBS (2.35 $\mathrm{g}, 0.26 \mathrm{mmol})$ and benzoyl peroxide $(3.19 \mathrm{~g}, 0.26 \mathrm{mmol})$ were suspended in $50 \mathrm{~mL}$ benzene. The mixture was heated to $80^{\circ} \mathrm{C}$ under stirring overnight. Excess solvent was removed under reduced pressure, and the crude yellow residue was recrystallized from $\mathrm{DCM} / \mathrm{MeOH}$ to yield 3.3 g product (yield 80\%). ${ }^{1} \mathrm{H}$ NMR $\left(\mathrm{CDCl}_{3}, 500 \mathrm{MHz}\right) \delta 9.30(\mathrm{~s}, 1 \mathrm{H}), 7.54(\mathrm{~s}, 2 \mathrm{H}), 6.19(\mathrm{~s}$, 2H), $4.16(\mathrm{~d}, J=6.4 \mathrm{~Hz}, 4 \mathrm{H}), 4.13(\mathrm{~s}, 6 \mathrm{H}), 2.39(\mathrm{~m}, 2 \mathrm{H}), 1.22(\mathrm{~d}, J=6.7 \mathrm{~Hz}, 12 \mathrm{H}) .{ }^{13} \mathrm{C} \mathrm{NMR}$ $\left(\mathrm{CDCl}_{3}, 500 \mathrm{MHz}\right) \delta 166.34,163.42,150.91,145.05,135.86,121.78,117.10,99.31,75.26$, 53.25, 28.27, 25.17, 19.14. MALDI-TOF MS: calcd for $\mathrm{C}_{25} \mathrm{H}_{30} \mathrm{~N}_{2} \mathrm{O}_{6}{ }^{+}[\mathrm{M}+\mathrm{H}]$ 533.1, found 532.5. 


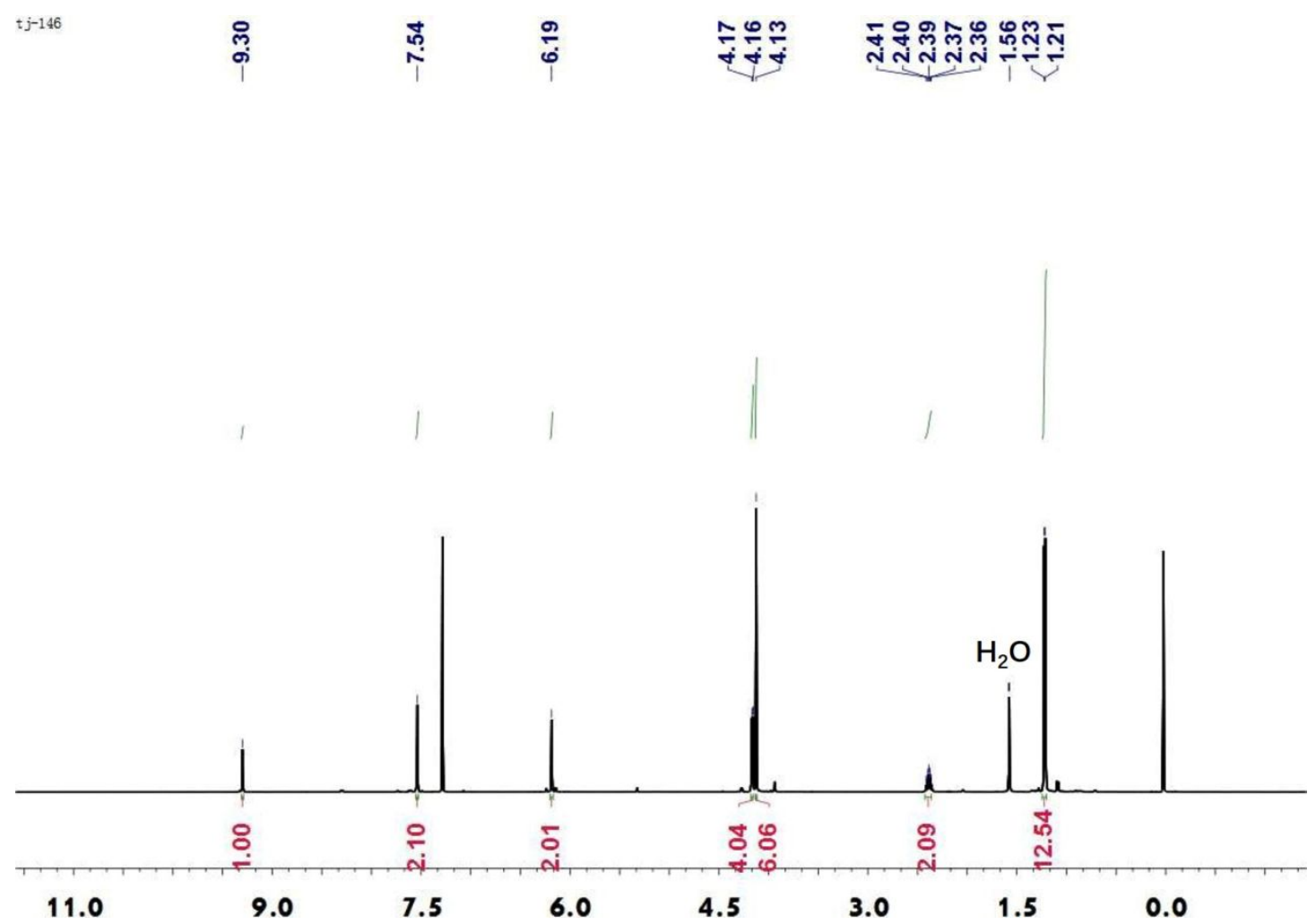

Figure S17. ${ }^{1} \mathrm{H}$ NMR spectrum of compound 5.

\begin{tabular}{|c|c|c|c|c|c|c|c|}
\hline 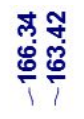 & 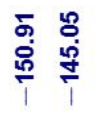 & $\begin{array}{l}\mathscr{0} \\
\stackrel{0}{0} \\
\stackrel{m}{1}\end{array}$ & 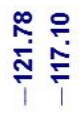 & ஸ़ & है & กึ & 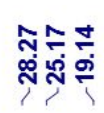 \\
\hline
\end{tabular}

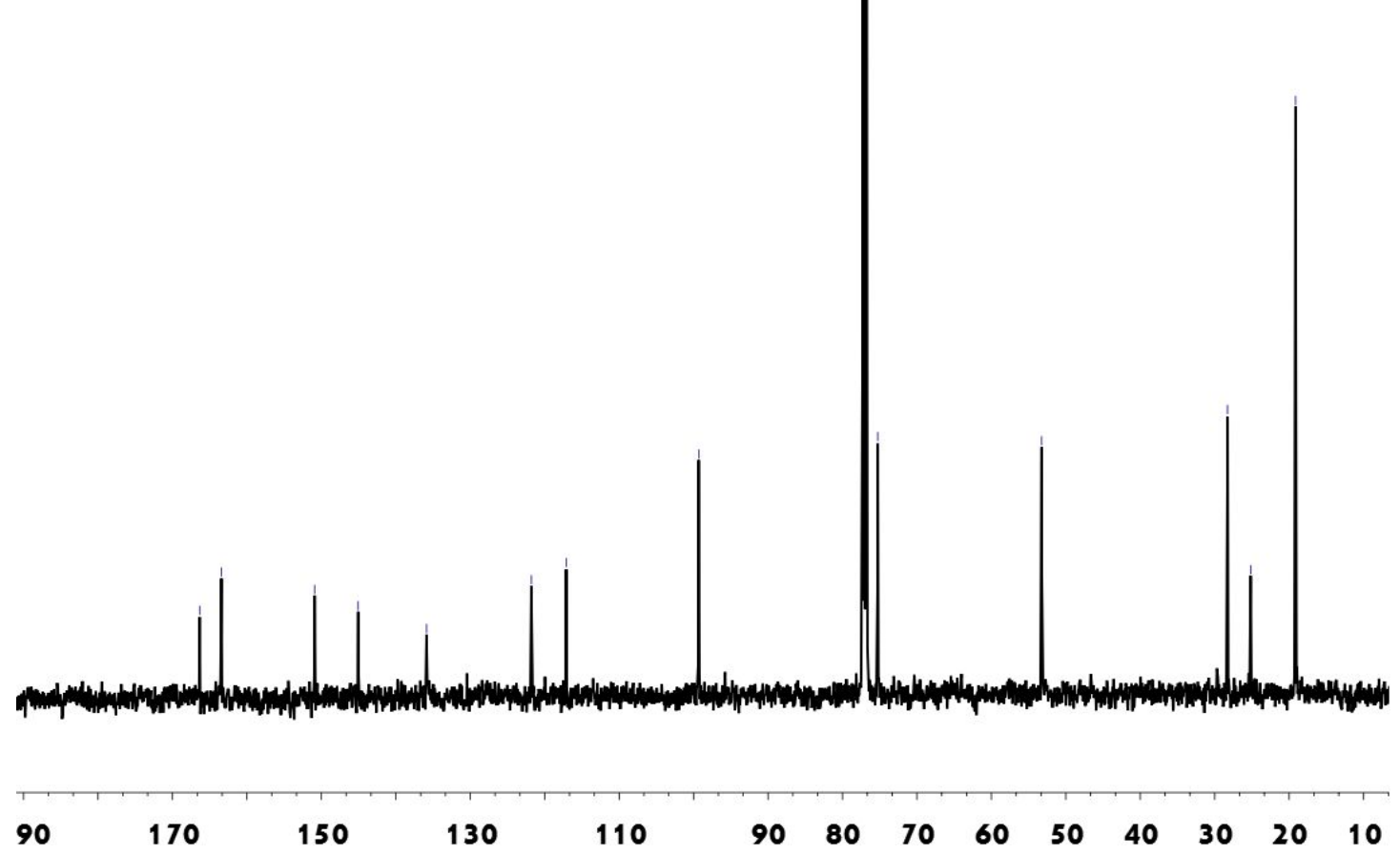

Figure S18. ${ }^{13} \mathrm{C}$ NMR spectrum of compound $\mathbf{5}$. 


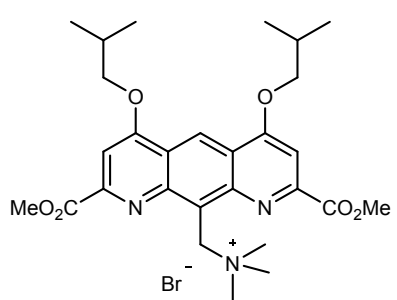

Compound 6. In a dry $100 \mathrm{~mL}$ round-bottomed flask, compound 5 (2.5 g, $0.16 \mathrm{mmol})$ and trimethylamine $(5 \mathrm{~mL}, 2.8 \mathrm{mmol})$ were stirring in $30 \mathrm{~mL} \mathrm{MeCN} / \mathrm{THF}=3: 1$ solvent at room temperature for $24 \mathrm{~h}$. Then excess solvent and trimethylamine were removed under reduced pressure and the crude product was filtered with cold $\mathrm{MeOH}$. The filter residue was dried in vacuum oven to produce $3.8 \mathrm{~g}$ yellow powder with yield $80 \%$. ${ }^{1} \mathrm{H}$ NMR (DMSO, $500 \mathrm{MHz}$ ): $\delta$ $9.39(\mathrm{~s}, 1 \mathrm{H}), 7.6(\mathrm{~s}, 2 \mathrm{H}), 4.29-4.28(\mathrm{~d}, 4 \mathrm{H}), 4.03(\mathrm{~s}, 8 \mathrm{H}), 3.19(\mathrm{~m}, 9 \mathrm{H}), 2.30-2.28(\mathrm{~m}, 2 \mathrm{H}), 1.16-$ $1.15(\mathrm{~d}, 12 \mathrm{H}) .{ }^{13} \mathrm{C} \mathrm{NMR}\left(\mathrm{CDCl}_{3}, 500 \mathrm{MHz}\right) \delta 165.41,164.06,152.13,147.08,124.45,121.67$, $121.58,99.69,60.62,54.99,53.57,28.23,19.09$. MALDI-TOF MS: calcd for $\mathrm{C}_{28} \mathrm{H}_{38} \mathrm{~N}_{3} \mathrm{O}_{6}{ }^{+}\left[\mathrm{M}^{+}\right]$ 512.2, found 512.5.

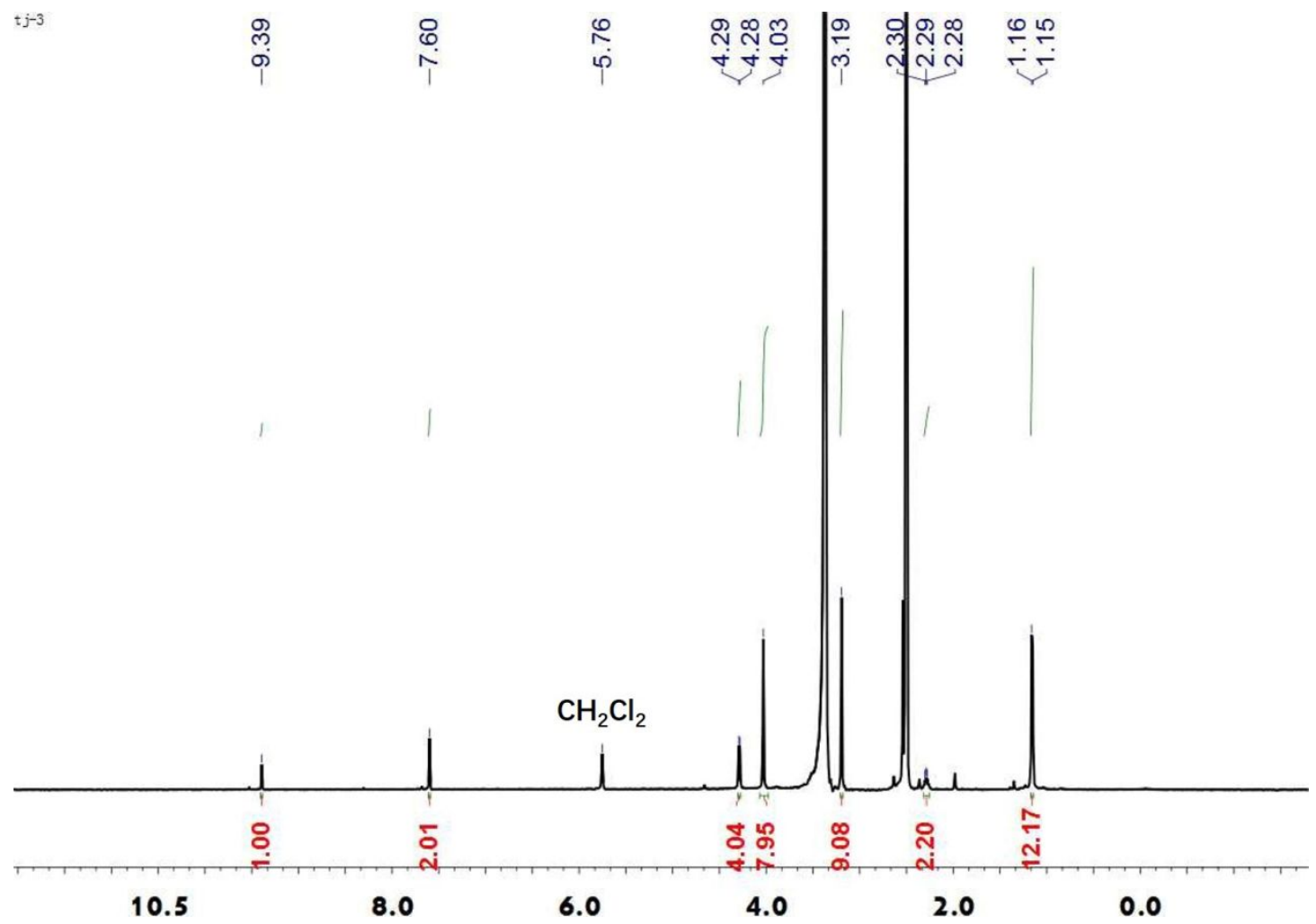

Figure S19. ${ }^{1} \mathrm{H}$ NMR spectrum of compound 6. 


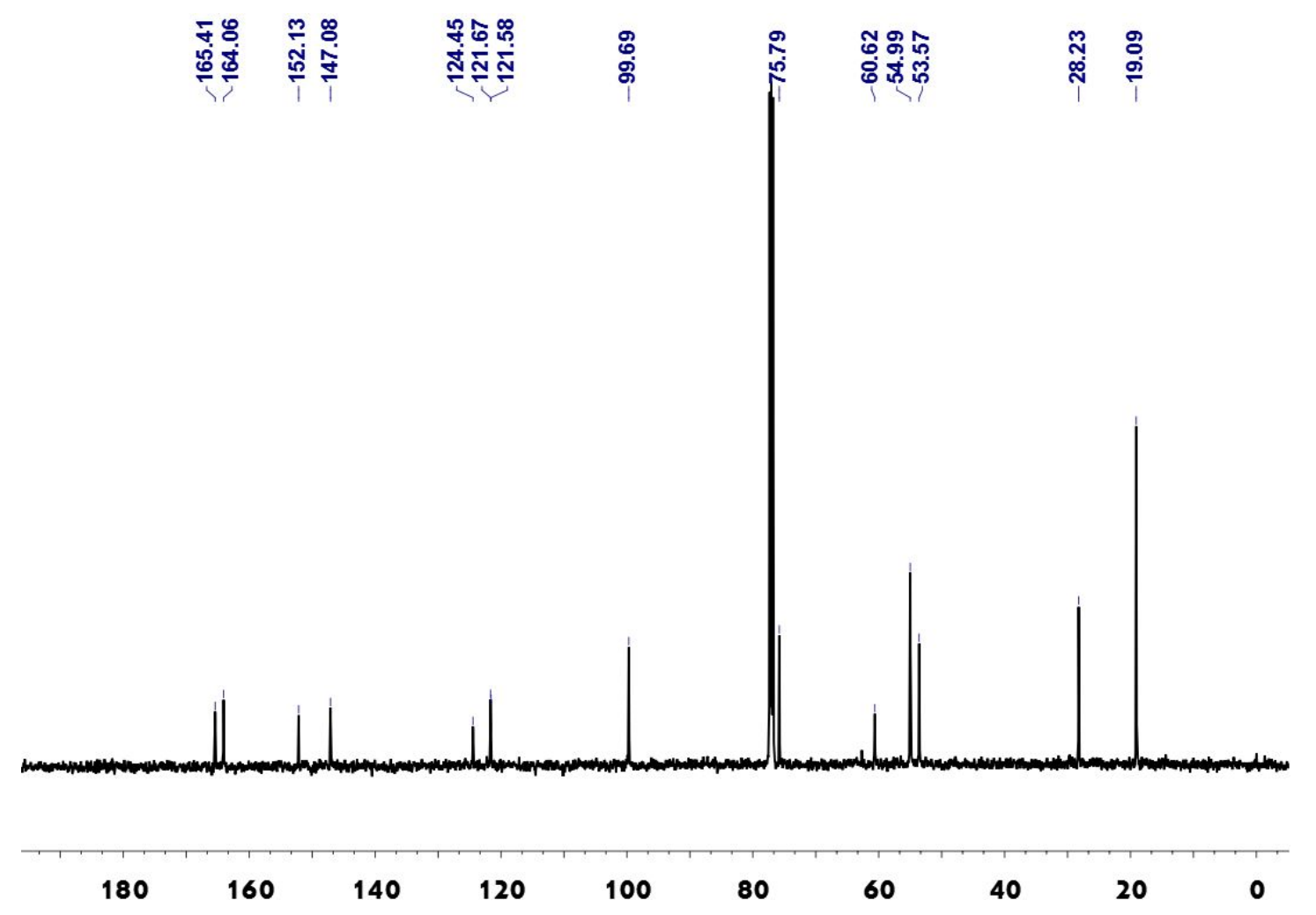

Figure S20. ${ }^{13} \mathrm{C}$ NMR spectrum of compound 6.<smiles>CC(C)COc1cc(C(=O)O)nc2c(CN(C)C)c3nc(C(=O)O)cc(OCC(C)C)c3cc12</smiles>

Compound 7. In a dry $100 \mathrm{~mL}$ round-bottomed flask, compound $6(1 \mathrm{~g}, 0.13 \mathrm{mmol})$ was dissolved in $15 \mathrm{~mL}$ methanol, $\mathrm{NaOH}(0.3 \mathrm{~g}, 0.52 \mathrm{mmol})$ and $1 \mathrm{~mL}$ water were added into the mixture under stirring at room temperature. After $24 \mathrm{~h}$, excess solvent was removed under reduced pressure and product was dispersed in water. The suspension was then neutralized with $0.1 \mathrm{M} \mathrm{HCl}$ and filtered with purified water. Finally, the filter residue was totally dried on vacuum at $50{ }^{\circ} \mathrm{C}$ for 2 days to get $0.9 \mathrm{~g}$ finial product (yield $\left.90 \%\right) .{ }^{1} \mathrm{H} \mathrm{NMR}\left(\mathrm{CDCl}_{3}, 500 \mathrm{MHz}\right)$ $\delta 9.30(\mathrm{~s}, 1 \mathrm{H}), 7.54(\mathrm{~s}, 2 \mathrm{H}), 6.19(\mathrm{~s}, 2 \mathrm{H}), 4.16(\mathrm{~d}, 4 \mathrm{H}), 4.13(\mathrm{~s}, 6 \mathrm{H}), 2.39(\mathrm{~m}, 2 \mathrm{H}), 1.22(\mathrm{~d}, 12 \mathrm{H})$. ${ }^{13} \mathrm{C}$ NMR (DMSO, $500 \mathrm{MHz}$ ) $\delta$ 166.85, 163.11, 152.29, 145.81, 137.16, 122.78, 117.74, 99.43, 74.79, 63.71, 58.13, 54.28, 28.24, 19.27. MALDI-TOF MS: calcd for $\mathrm{C}_{26} \mathrm{H}_{34} \mathrm{~N}_{3} \mathrm{O}_{6}{ }^{+}\left[\mathrm{M}^{+}\right]$484.2, found 484.5 . 


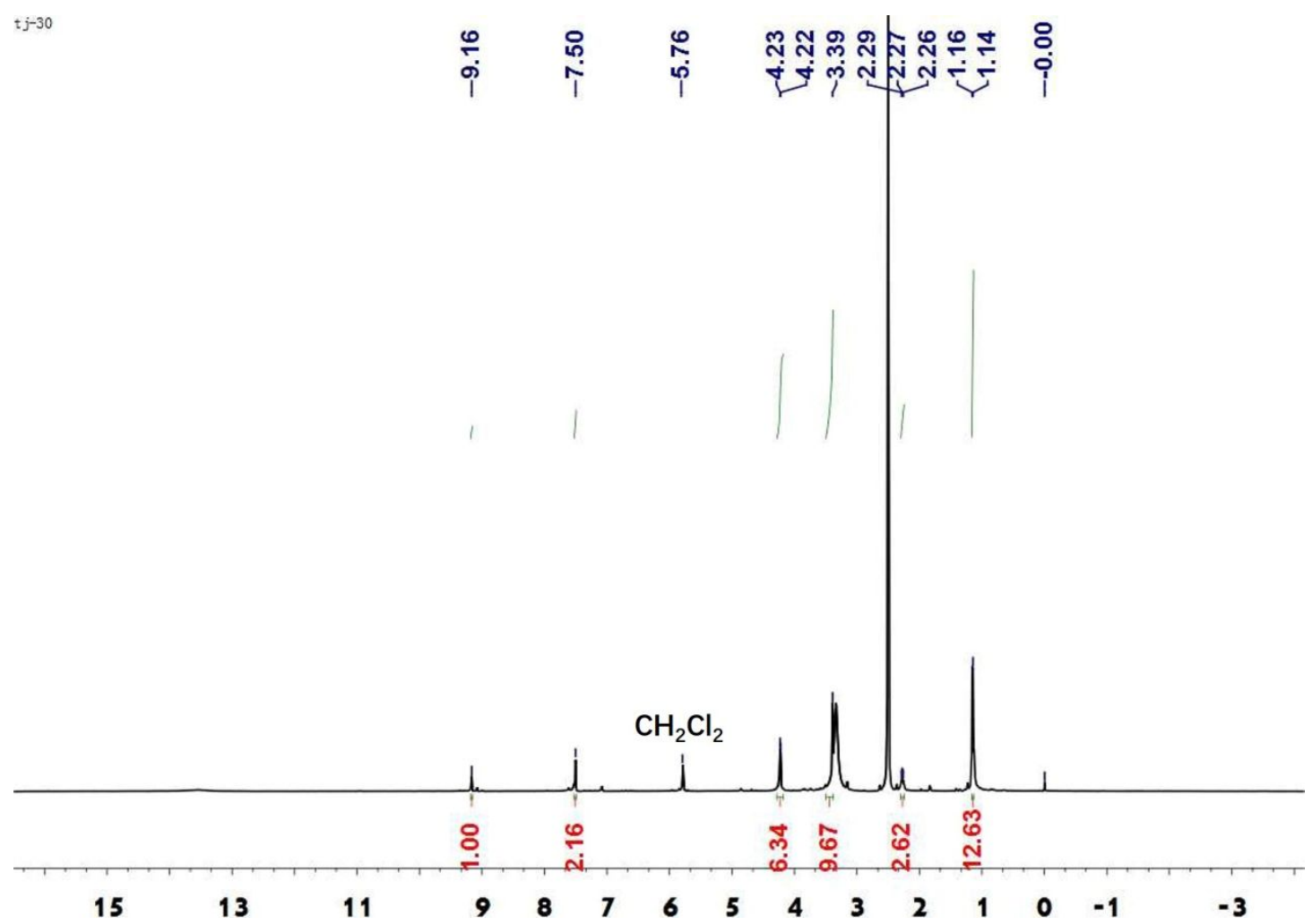

Figure S21. ${ }^{1} \mathrm{H}$ NMR spectrum of compound 7.

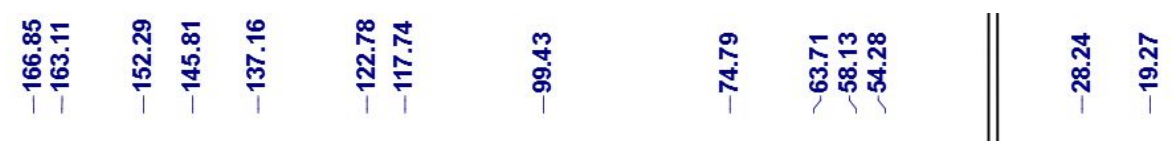
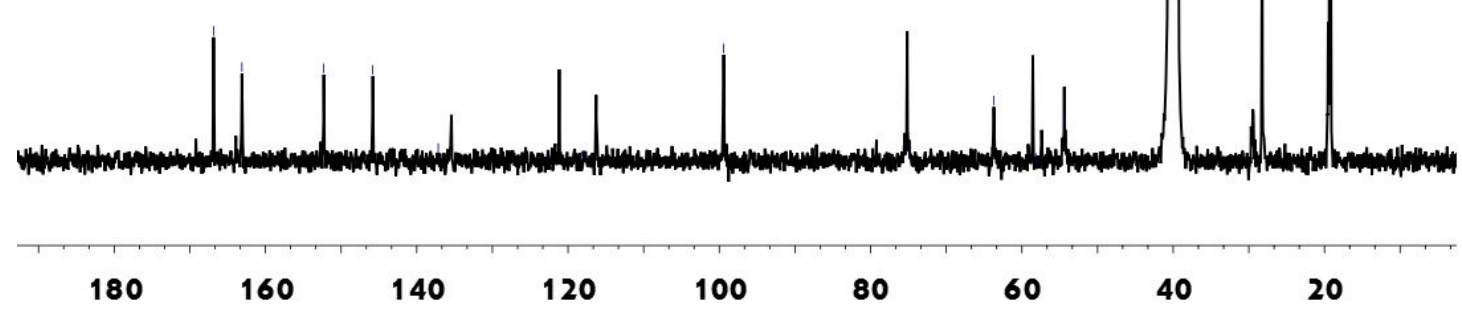

Figure S22. ${ }^{13} \mathrm{C}$ NMR spectrum of compound 7 . 
<smiles></smiles>

Compound 8. In a dry $100 \mathrm{~mL}$ round-bottomed flask, compound $7(0.5 \mathrm{~g}, 0.1 \mathrm{mmol})$ was dissolved in $10 \mathrm{~mL}$ dry $\mathrm{CHCI}_{3}$, excess oxalyl chloride $(1.7 \mathrm{ml}, 2 \mathrm{mmol})$ was added into flask under stirring in ice bath. The reaction mixture was then stirred at room temperature. After $24 \mathrm{~h}$, solvent and excess oxalyl chloride were removed under reduced pressure at $40{ }^{\circ} \mathrm{C}$ for 2 hours. In this step, reactions were only monitored by thin layer chromatography (TLC) due to the instabilities of the product. The product does not require further purification and goes straight to the next reaction.

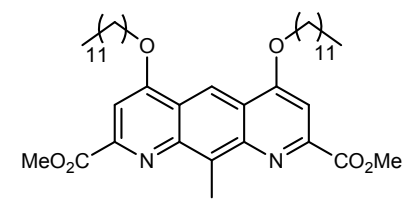

Compound 9. Compounds 9 was synthesized according to the previously reported methods and fully characterized. ${ }^{\mathrm{S} 2}$

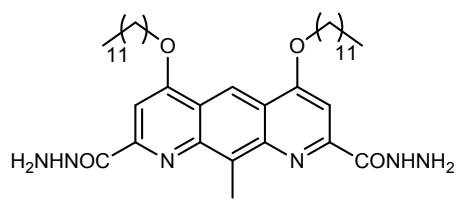

Compound 10. In a dry $100 \mathrm{~mL}$ round-bottomed flask, compound 9 ( $1 \mathrm{~g}, 0.098 \mathrm{mmol})$ was dissolved in $15 \mathrm{~mL}$ THF, excess hydrazine hydrate $(1.5 \mathrm{~mL}, 1.9 \mathrm{mmol})$ was added into the flask, the mixture was stirred at room temperature overnight. Then the reaction solvent was removed in vacuo, the crude product was recrystallized from $\mathrm{MeOH}$ to yield as a yellow powder (0.98 g, 98\%). ${ }^{1} \mathrm{H}$ NMR (DMSO, $500 \mathrm{MHz}$ ): $\delta 9.29$ (s, 1H), 9.07 (s, 1H), 7.59 (s, 2H), 4.39$4.37(\mathrm{t}, 4 \mathrm{H}), 4.18-4.17(\mathrm{~d}, 4 \mathrm{H}), 3.3(\mathrm{~s}, 3 \mathrm{H}) 2.05-2.01(\mathrm{~m}, 4 \mathrm{H}) 1.63-1.60(\mathrm{~m}, 4 \mathrm{H}) 1.45-1.25(\mathrm{~m}$, $32 \mathrm{H}), 0.88-0.85$ (t, 6H). ${ }^{13} \mathrm{C} \mathrm{NMR}\left(500 \mathrm{MHz}, \mathrm{CDCl}_{3}\right) \delta 165.16,163.87,150.61,144.98,136.02$, 121.26, 114.01, 96.48, 69.32, 31.93, 29.67, 29.37, 28.84, 26.11, 22.69, 14.11, 12.80; MALDITOF MS: calcd for $\mathrm{C}_{39} \mathrm{H}_{63} \mathrm{~N}_{6} \mathrm{O}_{4}{ }^{+}[\mathrm{M}+\mathrm{H}]$ : 679.4, found: 679.2 . 


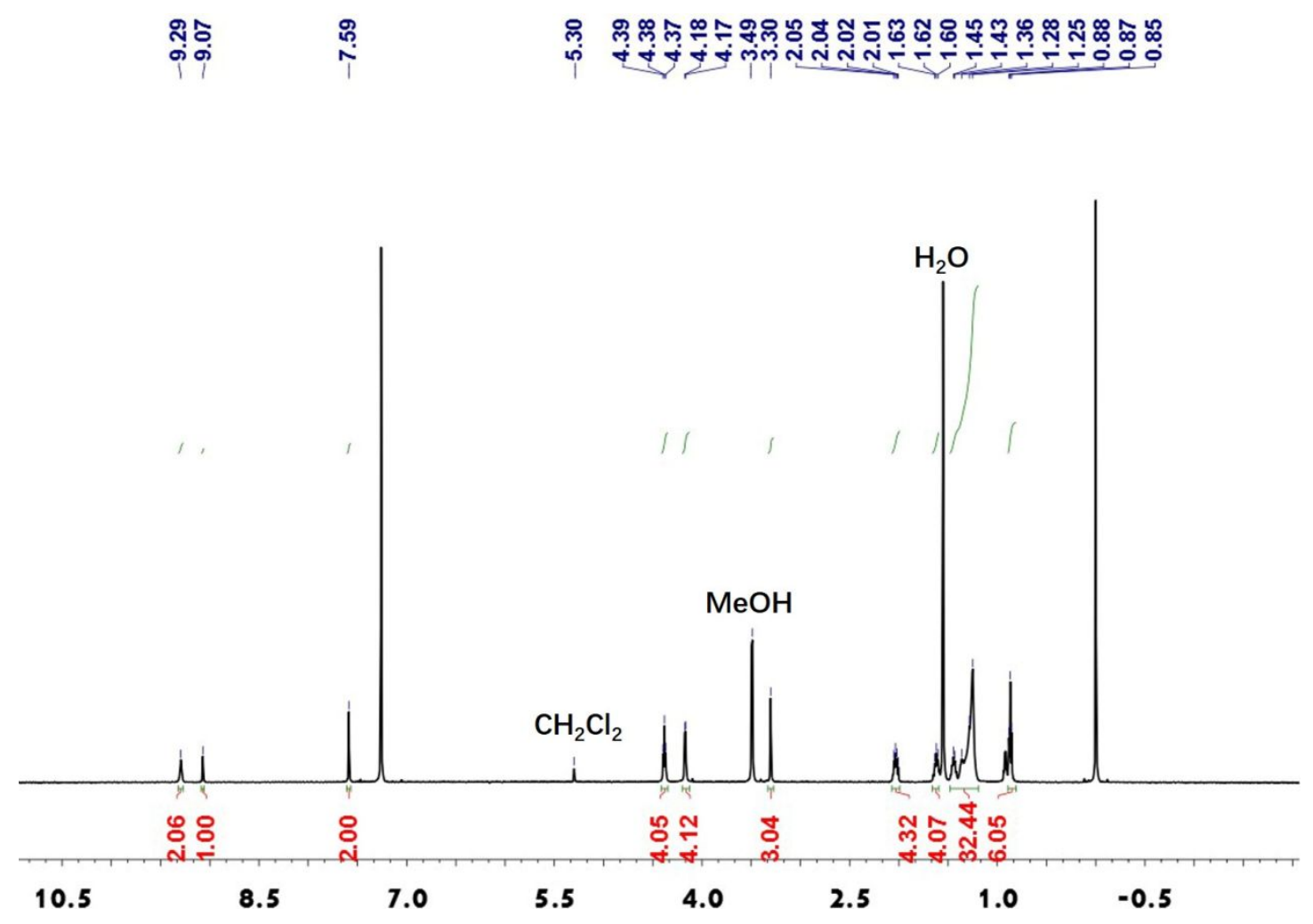

Figure S23. ${ }^{1} \mathrm{HNMRspectrum}$ of compound $\mathbf{1 0}$.

\begin{tabular}{|c|c|c|c|c|c|c|c|}
\hline 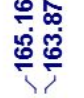 & 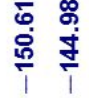 & 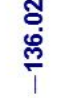 & 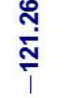 & $\underset{⿱ 亠 䒑}{+}$ & 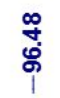 & స్ల్రి & 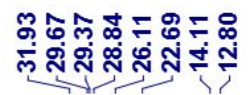 \\
\hline
\end{tabular}

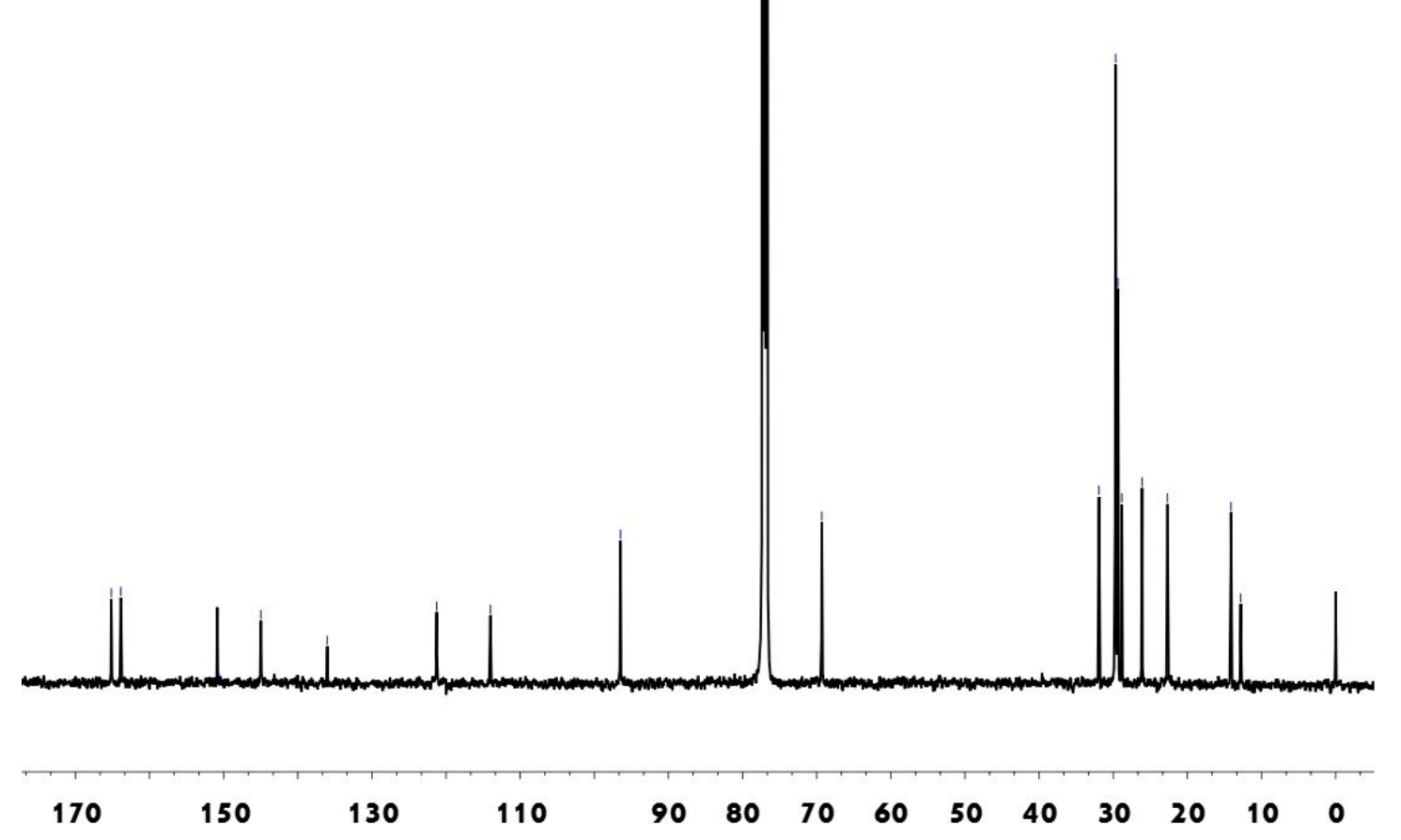

Figure S24. ${ }^{13} \mathrm{C}$ spectrum of compound $\mathbf{1 0}$. 


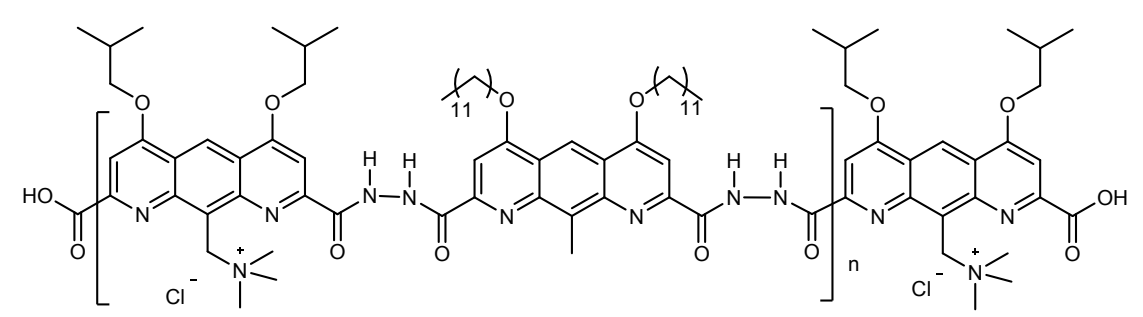

Compound 11. In a dry $100 \mathrm{~mL}$ round-bottomed flask, compound $8(0.22 \mathrm{~g}, 0.016 \mathrm{mmol})$ was dissolved in $20 \mathrm{~mL}$ dry $\mathrm{CHCI}_{3}$, then compound $10(0.17 \mathrm{~g}, 0.016 \mathrm{mmol})$ and triethylamine (3 $\mathrm{mL}, 2.12 \mathrm{mmol}$ ) were added. The reaction mixture was refluxed for $72 \mathrm{~h}$. Then the solvent was removed on vacuum, the crude product was recrystallized from $\mathrm{MeOH}$ to yield a brown powder $(0.35 \mathrm{~g})$. Compound $\mathbf{1 1}$ does not require further purification and was used directly for the next reaction.

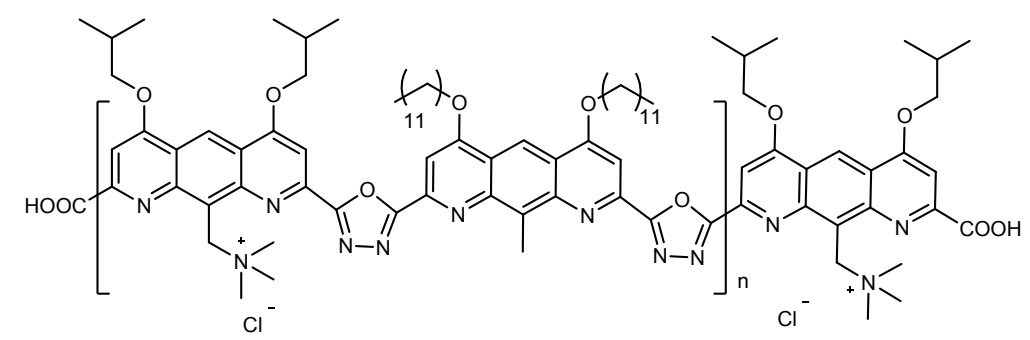

Compound 1. In a dry $100 \mathrm{~mL}$ round-bottomed flask, compound $11(0.3 \mathrm{~g}, 0.003 \mathrm{mmol})$ was dissolved in $20 \mathrm{~mL}$ dry $\mathrm{CHCI}_{3}$. Phosphorus oxychloride $(0.31 \mathrm{~mL}, 0.015 \mathrm{mmol})$ was dissolved in $5 \mathrm{~mL}$ dry $\mathrm{CHCI}_{3}$ then the mixture was dropwise added into the flask. The reaction mixture was heated under reflux for 3 days. After 3 days, the mixture was poured into $50 \mathrm{~mL}$ ice sodium bicarbonate aqueous solution and the organic phase was washed with brine for three times. The organic solvent was then removed on vacuum, and the crude product was recrystallized in $\mathrm{MeOH}$ to yield black powder $(0.3 \mathrm{~g}) .{ }^{1} \mathrm{H} \mathrm{NMR}\left(500 \mathrm{MHz}, \mathrm{CDCl}_{3}\right) \delta 9.49(\mathrm{~s}, 2 \mathrm{H}), 8.00(\mathrm{~s}, 4 \mathrm{H})$, $4.84-3.12$ (m, 22H), $2.46(\mathrm{~m}, 2 \mathrm{H}), 2.19(\mathrm{~m}, 4 \mathrm{H}), 1.79-1.00(\mathrm{~m}, 30 \mathrm{H}), 0.90(\mathrm{~s}, 6 \mathrm{H})$. IR [ $\left.\mathrm{cm}^{-1}\right]$ : $3205,2965,1667,1654,1572,1531,1372,1333,1274,1267,1211,1036,854,731,693$. GPC for 1: $\mathrm{Mn}=11941$, PDI: 1.09 . 


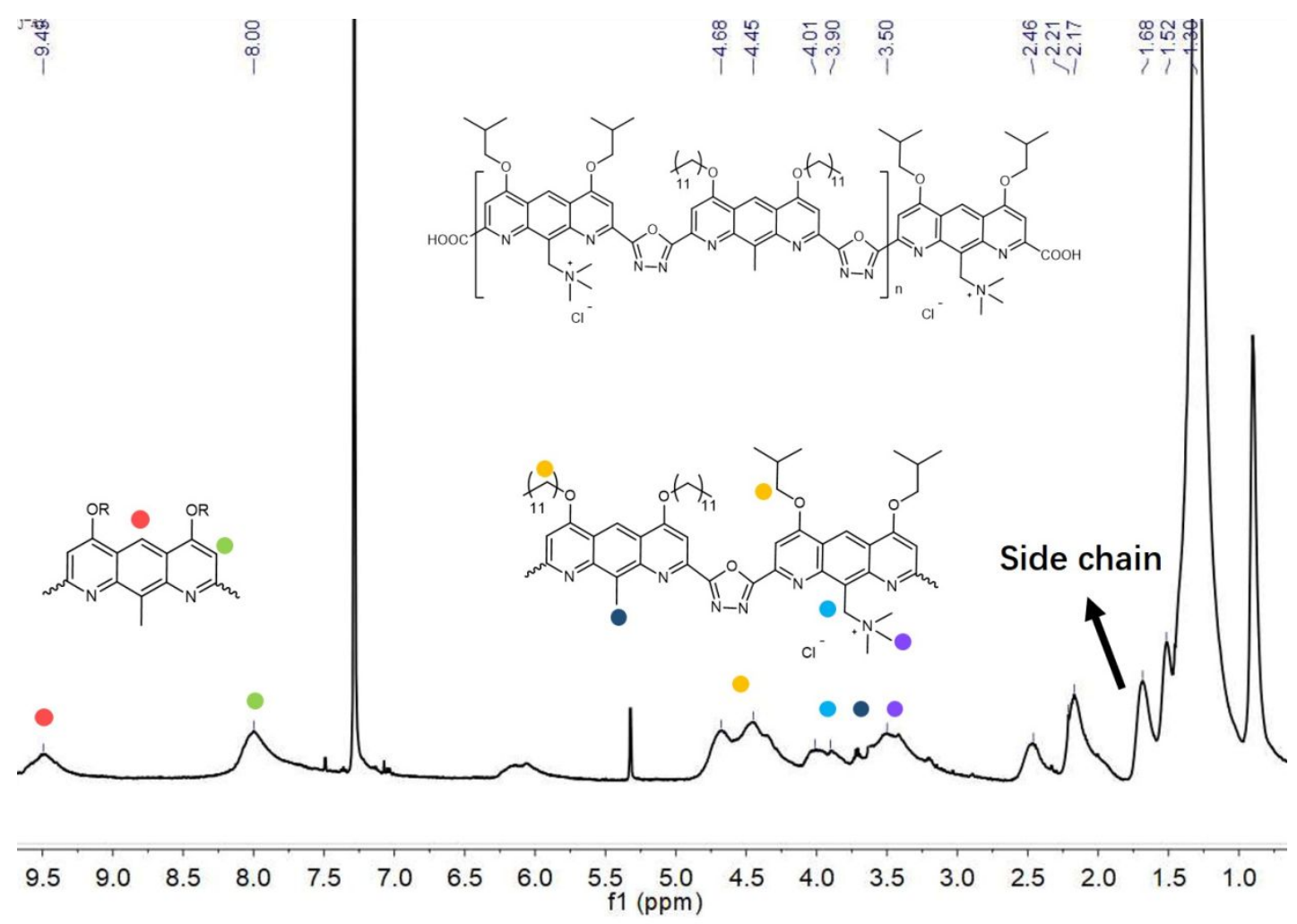

Figure S25. ${ }^{1} \mathrm{H}$ NMR spectrum of compound $\mathbf{1 .}$

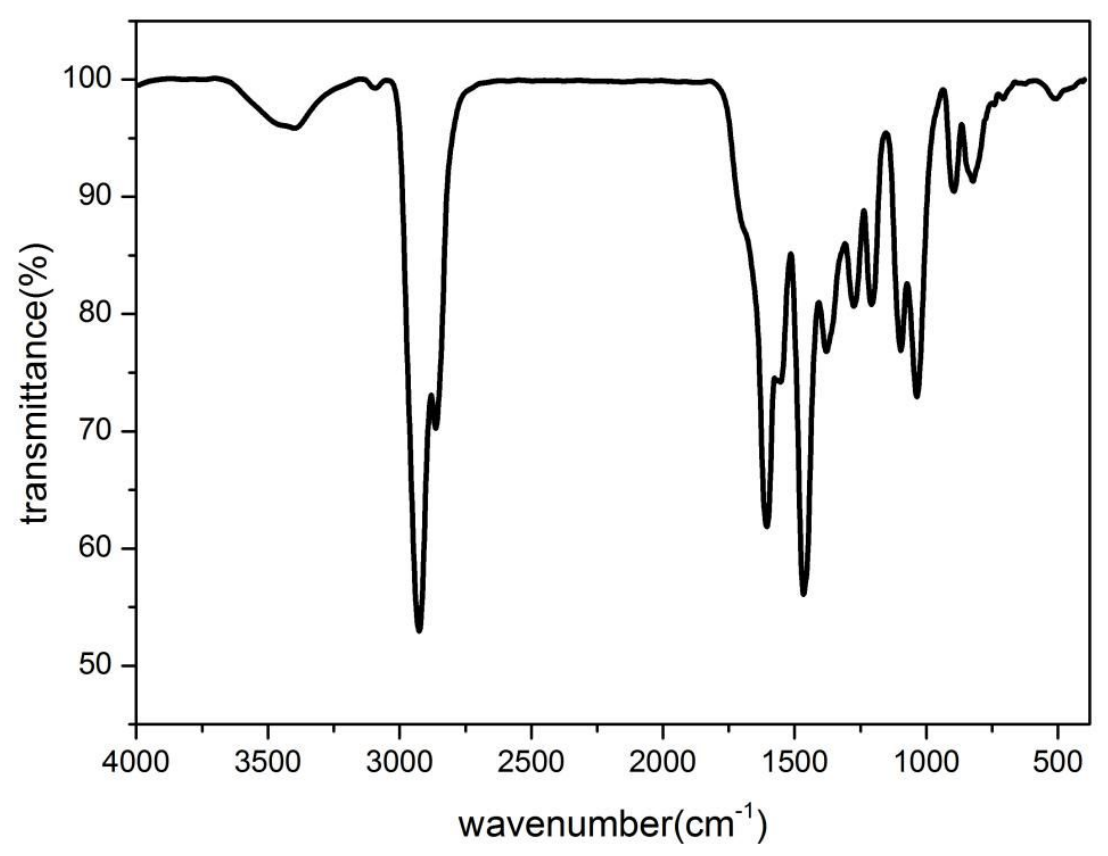

Figure S26. IR spectrum of compound 1. 


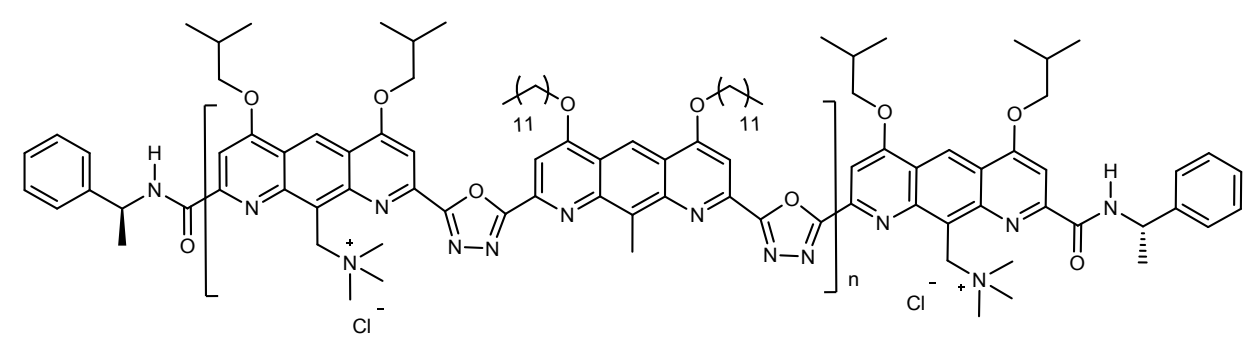

\section{Compound 2}

In a dry $50 \mathrm{~mL}$ round-bottomed flask, compound $1(0.1 \mathrm{~g}, 0.0013 \mathrm{mmol})$ was dissolved in 15 mL DMF. $(R)-(+)-1-P h e n y l e t h y l a m i n e ~(5 \mathrm{~mL}, 0.28 \mathrm{mmol})$, PyBop (200 mg, $0.0025 \mathrm{mmol})$ and triethylamine $(1 \mathrm{~mL}, 0.093 \mathrm{mmol})$ were added into the flask. The reaction mixture was stirred at $50^{\circ} \mathrm{C}$ for $24 \mathrm{~h}$. Then the reaction solvent was removed on vacuum, the crude product was recrystallized in $\mathrm{MeOH}$ to yield a black powder $(51 \mathrm{mg}) .{ }^{1} \mathrm{H} \mathrm{NMR}\left(500 \mathrm{MHz}, \mathrm{CDCl}_{3}\right) \delta 9.47$ (s, 2H), 7.98 (s, 4H), $4.86-4.12(\mathrm{~m}, 12 \mathrm{H}), 4.06-3.78(\mathrm{~m}, 4 \mathrm{H}), 3.54-3.21(\mathrm{~s}, 6 \mathrm{H}), 2.44(\mathrm{~m}$, 2H), 2.15 (m, 2H), $1.75-1.03(\mathrm{~m}, 30 \mathrm{H}), 0.88$ (s, 6H). IR [ $\left.\mathrm{cm}^{-1}\right]: 3050,2923,1687,1566,1534$, 1482, 1465, 1407, 1322, 1201, 1178, 1085, 853. 731, 699.

\section{References}

S1. J. Zhu, Z. Dong, S. Lei, L. Cao, B. Yang, W. Li, Y. Zhang, J. Liu, J. Shen, Angew. Chem. Int. Ed. 2015, 54, 3097.

S2. C. Lang, W. Li, Z. Dong, X. Zhang, F. Yang, B. Yang, X. Deng, C. Zhang, J. Xu, J. Liu, Angew. Chem. Int. Ed. 2016, 55, 9723. 